\title{
Murine- $\beta$-coronavirus-induced neuropathogenesis sheds light on CNS pathobiology of SARS-CoV2
}

\author{
Debanjana Chakravarty ${ }^{1} \cdot$ Jayasri Das Sarma ${ }^{1,2}$ (])
}

Received: 9 October 2020 / Revised: 29 December 2020 / Accepted: 12 January 2021 / Published online: 5 February 2021

(c) Journal of NeuroVirology, Inc. 2021

\begin{abstract}
The pandemic caused by SARS-CoV-2 has caused widespread infection and significant mortality across the globe. Combined virology perspective of SARS-CoV-2 with a deep-rooted understanding of pathophysiological and immunological processes underlying the clinical manifestations of COVID-19 is of prime importance. The characteristic symptom of COVID-19 is respiratory distress with diffused alveolar damage, but emerging evidence suggests COVID-19 might also have neurologic consequences. Dysregulated homeostasis in the lungs has proven to be fatal, but one cannot ignore that the inability to breathe might be due to defects in the respiratory control center of the brainstem. While the mechanism of pulmonary distress has been documented in the literature, awareness of neurological features and their pathophysiology is still in the nascent state. This review makes references to the neuro-immune axis and neuro-invasive potential of SARS-CoV and SARS-CoV2, as well as the prototypic H-CoV strains in human brains. Simultaneously, considerable discussion on relevant experimental evidence of mild to severe neurological manifestations of fellow neurotropic murine- $\beta$-CoVs (m-CoVs) in the mouse model will help understand the underpinning mechanisms of Neuro-COVID. In this review, we have highlighted the neuroimmunopathological processes in murine CoVs. While MHV infection in mice and SARS-CoV-2 infection in humans share numerous parallels, there are critical differences in viral recognition and viral entry. These similarities are highlighted in this review, while differences have also been emphasized. Though CoV-2 Spike does not favorably interact with murine ACE2 receptor, modification of murine SARS-CoV2 binding domain or development of transgenic ACE-2 knock-in mice might help in mediating consequential infection and understanding human CoV2 pathogenesis in murine models. While a global animal model that can replicate all aspects of the human disease remains elusive, prior insights and further experiments with fellow m- $\beta$-CoV-induced cause-effect experimental models and current human COVID-19 patients data may help to mitigate the SARS-CoV-2-induced multifactorial multi-organ failure
\end{abstract}

Keywords Coronavirus $\cdot$ Spike protein $\cdot \mathrm{SARS}-\mathrm{CoV} 2 \cdot \mathrm{m}-\mathrm{CoV} \cdot \mathrm{MHV} \cdot$ Neurological manifestations (meningitis · Encephalitis · Acute myelitis · Myelin loss in the CNS and PNS) - Virus persistence · IFNs · Cytokine storm ·

Lymphocytopenia

\section{Introduction}

Coronaviruses (CoVs) are large enveloped non-segmented positive-sense RNA viruses and potent pathogens for humans and animals, usually associated with respiratory,

Jayasri Das Sarma

dassarmaj@iiserkol.ac.in

1 Department of Biological Sciences, Indian Institute of Science Education and Research Kolkata, Haringhata, 741246 Mohanpur, India

2 Department of Ophthalmology, University of Pennsylvania, Philadelphia, PA 19104, USA gastrointestinal, hepatic, and neurological diseases (de Wilde et al. 2018; Fehr and Perlman 2015; Weiss and Leibowitz 2011; Weiss and Navas-Martin 2005). Prototype human-CoVs (H-CoVs), such as 229E, OC43, NL63, and HKU1, cause mild respiratory disorders (Corman et al. 2018; Esper et al. 2005; van der Hoek et al. 2006; Woo et al. 2005). Previously, two emergent CoVs, the severe acute respiratory syndrome CoV (SARS-CoV) and Middle East respiratory syndrome $\mathrm{CoV}$ (MERS-CoV), have drawn global attention for their aggressive virulence and potential lethality, aggravated by severe respiratory distress (de Wit et al. 2016; Perlman and Netland 2009). However, the recent emergence of deadly novel H-CoV, SARS-CoV-2 due to 
its heightened zoonotic potential, virulence, and sustained lethality has led the entire world into COVID 19 crisis, and the human health is at risk (Zhou et al. 2020a; Zhu et al. 2020). There is an urgent need to better understand the host-pathogen interaction and pathobiology of SARSCoV-2 inducing COVID-19 to identify and design rational therapeutic strategies. This current understanding of SARSCoV2 pathobiology stems primarily from differential patients' data with minimal experimental evidence with limitations. Critical barriers like limited access to biosafety level 3 laboratories to work with SARS-CoV-2 and lack of reliable animal models until now demands the utilization of existing experimental animal models to comprehend the cause-effect mechanism of immunoregulation and molecular mechanism of host immune response against CoV2.

Mouse hepatitis virus (MHV), a fellow $\beta$-coronavirus, provides an excellent experimental platform to understand the pathobiology of respiratory, enteric, hepatic, and neurological manifestation due to their differential organ tropism, similar to human-CoVs (Bender and Weiss 2010; Das Sarma 2010, 2014; Das Sarma et al. 2001; Fleming et al. 1986; Lavi et al. 1984b; Stohlman and Weiner 1981; Tardieu et al. 1986, 1982). There are five naturally occurring, well known, and thoroughly studied strains of MHV. MHV-1 induces respiratory disease (De Albuquerque et al. 2006), similar to SARS-CoV and SARS-CoV2. Whereas MHV-3 results in hepatitis, thrombosis in the liver (like SARS$\mathrm{CoV} 2$ induces thrombosis in the brain), vasculitis, initial epididymitis, meningitis, and encephalitis but does not induce lesions in the white matter of the CNS (Tardieu et al. 1986). MHV-JHM, along with MHV-A59 and its isogenic recombinant strains, have been studied for ages as a mouse model of virus-induced acute stage meningitis, encephalitis, myelitis, and chronic progressive demyelination concurrent with axonal loss of the CNS (Das Sarma 2010, 2014; Das Sarma et al. 2008, 2009; Houtman and Fleming 1996; Lavi et al. 1984b; Stohlman and Weiner 1981). All the different strains of MHV have been highlighted in Table 1. Despite several similarities in viral structure, organ tropism, and disease course, a critical difference between strains of MHV and SARS-CoV-2 is in their viral receptor (CEACAM1a without co-receptors for MHV and ACE2 with co-receptors for SARS-CoV2). Thus, MHV can provide some insights into the viral biology of SARS-CoV-2, though it may not wholly recapitulate the vividity of this new virus, due to differences in virus entry or recognition. Even if the knowledge from fellow murine- $\beta$-CoV-induced model may not be extrapolated directly into human SARS-CoV2 studies, it may provide proof-of-concept data and act as a surrogate model or framework, especially for the neuro$\mathrm{CoV} 2$ pathogenesis studies.

The significant impediment in establishing murine models of SARS-CoV2 is the lack of proper receptors in mice. Murine ACE-2 does not efficiently bind to CoV2 spike protein. It should be emphasized that while SARS$\mathrm{CoV} 2$ utilizes ACE-2 as its cognate receptor, m-CoV uses CAECAM-1 receptor to initiate infection. Studies are aimed at resolving these issues by developing humanized mouse
Table 1 Different strains of MHV

\begin{tabular}{lll}
\hline Strain & Organ-tropism & Disease caused \\
\hline MHV-1 & Pneumotropic & Respiratory distress \\
& & Pneunonitis (inflammation in lungs) \\
MHV-3 & Neurotropic, hepatotropic & Hepatitis (inflammation in liver) \\
& & Vasculitis (inflammation of blood vessels), \\
& & Initial ependymitis (inflammation of ependy- \\
& mal cells in BBB) \\
& & Meningitis (inflammation of meninges) \\
& & Encephalitis (inflammation in Brain Paren- \\
& chyma) \\
MHV-JHM & Highly neurotropic & Meningitis \\
& & Encephalitis \\
& & Myelitis (Inflammation in spinal cord) \\
& Demyelination (loss of myelin sheath on axons) \\
MHV-A59 & Neurotropic, hepatotropic & Hepatitis \\
& & Meningitis \\
& & Encephalitis \\
& & Optic neuritis (Inflammation of optic nerve) \\
& Myelitis \\
& & Demyelination and axonal loss \\
& & Retinal ganglionic cell degeneration \\
& & Hepatitis \\
& ability to enter CNS & Limited meningitis \\
\hline
\end{tabular}


models that express the hACE2 receptor, modifying CoV2 spike to effectively bind with murine-ACE2, studying aged mice strains to mimic conditions in old-age human patients, utilizing several knockout mice strains intending to replicate the mechanisms involved in human infection (MuñozFontela et al. 2020). However, these models are preliminary, and CNS pathobiology has not been well studied in these models yet. Though our understanding of the SARS-CoV-2 impact on CNS and its pathogenesis is rudimentary, however evolving precipitously, we hope that this review will provide a useful scaffold and help understand the many neurologic mechanisms of COVID-19 using insights from m-CoVs.

\section{Preview of $\mathrm{H}-\mathrm{CoV}$ pathogenesis and their neurological manifestations}

The largest known RNA viruses, CoVs, are divided into four genera: $\alpha$-CoVs, $\beta$-CoVs, $\gamma$-CoVs, and $\delta$-CoVs. To date, six human coronaviruses (HCoVs) have been recognized; among them are the $\alpha-\mathrm{CoVs}$ (NL63 and 229E) and the $\beta$-CoVs [ $(\mathrm{OC} 43$, HKU1), severe acute respiratory syndromeCoV (SARS-CoV and SARS-CoV-2), and Middle East respiratory syndrome-CoV (MERS-CoV)] (Forni et al. 2017; Su et al. 2016). $\gamma$-coronaviruses are known to infect only avian species, and $\delta$-coronaviruses can infect both mammalian and avian species (Su et al. 2016). New CoVs have appeared to emerge periodically in humans, mainly due to the high prevalence, vast genetic diversity, frequent recombination of their genomes, and the ever-increasing human-animal interface. HCoVs- 229E, -OC43, -NL63, and -HKU1 trigger mild common seasonal cold symptoms, whereas the severe respiratory syndrome can be induced by SARS-CoV, the MERS-CoV, and SARS-CoV-2 infection (Corman et al. 2018; de Wit et al. 2016; Esper et al. 2005; Forni et al. 2017; Perlman and Netlan 2009; van der Hoek et al. 2006; Woo et al. 2005).

Cellular entry of coronaviruses depends upon the binding of the viral spike (S) protein to a specific cellular receptor and subsequent $\mathrm{S}$ protein priming by cellular proteases $(\mathrm{Du}$ et al. 2009; Shirato et al. 2013; Walls et al. 2016). SARS$\mathrm{CoV}$ and SARS-CoV-2 employ Angiotensin-converting enzyme 2 (ACE2) as a receptor for cellular entry, whereas MERS deploy dipeptidyl peptidase 4 (DPP4) (Hoffmann et al. 2020; Li et al. 2003; Raj et al. 2013). The binding affinity of the S protein and ACE2 was found to be a significant determinant of SARS-CoV and SARS-CoV-2 replication rate and disease severity (Hoffmann et al. 2020; Li 2015; Shang et al. 2020b; Zhou et al. 2020a). SARSCoV2 virus entry also depends on TMPRSS2 protease activity (Hoffmann et al. 2020). However, pre-activation by prior cleavage of the proprotein convertase furin reduces SARS-CoV2 dependency on cellular proteases for entry, unlike SARS-CoV infection (Shang et al. 2020a). ACE2 and TMPRSS2 have been detected in both nasal and bronchial epithelium, more specifically in alveolar epithelial type II cells, which are central to SARS-CoV-2 entry and pathogenesis (Ziegler et al. 2020).

Accruing evidence from animal models and studies of $\mathrm{H}$-CoVs suggests a neurotropic potential of these viruses (Arbour et al. 2000; Jacomy et al. 2006; van der Hoek 2007). Two different serogroups of H-CoVs, OC43, and 229E, primarily denoted as respiratory tract pathogens, are known to cause up to one-third of the common colds but can also induce pneumonia, meningitis, radiculitis, and diarrhea (Corman et al. 2018; Esper et al. 2005; van der Hoek 2007). Other virulent and epidemic strains of $\mathrm{H}-\mathrm{CoV}$ s are also associated with rare CNS and PNS manifestations. Encephalitis, encephalopathy, acute disseminated encephalomyelitis, acute-flaccid paralysis, motor neuropathy, myopathy, cerebrovascular disorder, rare post/para infectious Bickerstaff's brainstem encephalitis, and various other neurological symptoms like headache, neck stiffness, and seizures have been observed with several H-CoV infections like SARS-CoV, MERS-CoV, OC43, and 229E in humans in the past decade (Hung et al. 2003; Jacomy et al. 2006; Kim et al. 2017; Lau et al. 2004; Morfopoulou et al. 2016; Turgay et al. 2015). In fact, SARS-CoV was detected in cerebrospinal fluid (CSF) by RT-PCR (Gu and Korteweg 2007; Hung et al. 2003). Various continuous human neural cell lines and specifically both human fetal astrocytes and adult microglia get infected with H-CoV strain-OC43 (Arbour et al. 1999a). Similarly, RNA amplification revealed infection of fetal astrocytes, adult microglia, and a mixed culture of adult oligodendrocytes and astrocytes by strain 229E (Arbour et al. 1999b; Talbot et al. 1993). Mice are naturally susceptible to infection with $\mathrm{H}-\mathrm{CoV} \mathrm{OC} 43$ human strain. Intranasal infection in the miceinduced neurological symptoms, similar to human patients infected from $\mathrm{H}-\mathrm{CoVs}$, with long-term viral persistence (Jacomy et al. 2006; Jacomy and Talbot 2003).

\section{Overview of SARS-CoV2 systemic pathogenesis with a special emphasis on its neurological manifestations}

Present studies suggest that the pathogenesis initiates with SARS-CoV-2 entry through the nasal epithelium, which acts as a portal for initial infection and transmission ( $\mathrm{Wu}$ et al. 2020a; Xu et al. 2020a). Virus replication initiates in the lungs, causing damage to pneumocytes, stemming into diffuse alveolar damage and loss of function (Menter et al. 2020; Schaefer et al. 2020; Xu et al. 2020b). However, pneumocytes in the lungs and lower respiratory tract are merely the first targets; this virus can infect various other 
organs, including the eyes, kidneys, intestines, heart, testes, blood vessels, and brain (Guan et al. 2020; Huang et al. 2020; Mao et al. 2020). Reports so far identified angiotensinconverting enzyme 2 (ACE2) as a receptor for SARS-CoV2, which provided an insight into its cellular entry and tropism (Hoffmann et al. 2020; Letko et al. 2020; Shang et al. 2020b; Walls et al. 2020; Wrapp et al. 2020; Ziegler et al. 2020).

Further studies also confirmed that the interaction of ACE-2 with the Receptor Binding Domain of the CoV-2 spike protein is the primary driver of this disease phenomenon (Hoffmann et al. 2020; Shang et al. 2020b; Wrapp et al. 2020; Zhou et al. 2020a). The scope and nature of the detriment are dependent upon the modulation of ACE-2 in the Renin-angiotensin pathway and the consequent immune stimulation (Wang et al. 2020). Equilibrium of the inflammatory response is a critical frontier in CoV2 tropism. Rapid replication and elevated viral titer in COVID-19 promote systemic cytokine release as a defense mechanism. However, if dysregulated, it causes immunopathological injury to the organs (García 2020; Henderson et al. 2020). Therefore, a timely switch from the host proinflammatory response to the subsequent immunosuppressive stage is the critical checkpoint for defining CoV2 infection. On the one hand, overactivation of the immune system can produce "cytokine storm" leading to lung inflammation, fluid accumulation, and thrombosis. On the other hand, dampened cytokine response can lead to uncontrolled viral replication, which can be manifested as severe clinical symptoms.

Although a dysregulated homeostasis in the lungs has proven to be fatal in COVID-19, mounting evidence is reporting that SARS-CoV-2 is not only confined to the respiratory tract but can also invade the central nervous system (CNS), inducing neurological complications, such as headache, nausea, and vomiting (Koralnik and Tyler 2020; Mao et al. 2020). Neurological symptoms may start as early as days 3-7 with or after respiratory or systemic features. From the pathological aspect, recent studies reported that COVID-19 patients exhibit CNS meningoencephalomyelitis, acute disseminated encephalitis, ischemic and hemorrhagic stroke, venous sinus thrombosis, and endothelialitis (Frontera 2012; Koralnik and Tyler 2020; Mao et al. 2020; Moriguchi et al. 2020; Oxley et al. 2020; Poyiadji et al. 2020; Varga et al. 2020). Some very recent studies suggested the possibility of demyelinating lesions in the white matter of the brain and spinal cord (Brun et al. 2020; Reichard et al. 2020; Zanin et al. 2020; Zoghi et al. 2020). In the peripheral nervous system (PNS), COVID-19 has been associated with dysfunction of smell and taste, muscle injury, difficulty concentrating, altered consciousness, neuropsychiatric disorders, focal seizures, and the Guillain-Barre syndrome (GBS) with weakness of limbs with or without sensory loss.(Gautier and Ravussin 2020; Gutiérrez-Ortiz et al. 2020; Helms et al. 2020; Koralnik and Tyler 2020; Toscano et al. 2020). Variants of GBS like Miller Fischer syndrome and polyneuritis cranialis have also been noted (Gutiérrez-Ortiz et al. 2020; Toscano et al. 2020). Some studies showed the presence of SARS-CoV2 in the cerebrospinal fluid (Moriguchi et al. 2020; Wu et al. 2020b). Another study highlighted the ability of SARS$\mathrm{CoV} 2$ to replicate in neuronal cell in vitro (Chu et al. 2020). Reports suggested a potential sympathetic storm in the CNS of COVID-19 patients, leading to seizure-like reflexes ( $\mathrm{Lu}$ et al. 2020; Manganelli et al. 2020). The lungs' inability to procure oxygen might be partially due to the defects in the respiratory control center of the brainstem ( $\mathrm{Li}$ et al. 2020; Manganelli et al. 2020). Thus, the pandemic nature, co-morbidities, and multifactorial pathogenic mechanisms of COVID-19 pose a global threat to the entire nervous system.

Neuroinvasion of SARS-CoV2 and its potential contribution in the pathobiology of respiratory failure in patients with COVID-19 establishes a lung-brain axis in the COVID-19 pathobiology, which may have a steering implication for the development of preventive therapeutics and treatment of SARS-CoV-2-induced respiratory failure as well as other neurological complications. While a whole-hearted attempt is going on to understand patients' asymptomatic and symptomatic disease processes, we cannot disregard the possibility of viral persistence in the recovered patients. $\beta$-coronaviruses mRNA is known for its persistence, even when the infectious virus particles get cleared, and acute inflammation gets resolved (Das Sarma 2010, 2014; Das Sarma et al. 2000; Lane and Buchmeier 1997; Lavi et al. 1984a; Perlman et al. 1990). The persistence of viral RNA can be a prerequisite for chronic stage progressive disease in recovered patients. Apart from direct cytopathic damage by SARS-CoV2 replication in CNS (induced by systemic propagation and binding to ACE-2 receptor in the CNS), an immune-mediated systemic response can also induce secondary neuropathological manifestations as a result of hypoxia, sepsis, cytokine storm, and multi-organ failure upon SARS-CoV2 infection. In those cases where the virus was not detected in the CNS, reports suggested that the neuropathological changes may be secondary to the severe systemic inflammation. For example, ischemic/hypoxic encephalopathy could be due to reduced oxygen supply to the brain, which may result from cytokine storm-induced pneumonia (Al-Sarraj et al. 2020). Acute cerebrovascular accidents were also reported which could occur due to the global hypercoagulable state of the body, evidenced by increased D-Dimers, prolonged prothrombin time, hemorrhagic infarctions, and endothelial injury (González-Pinto et al. 2020). One clinical data also noted brain resident microglial cell activation in COVID-19 patients to be parallelly associated with diffused alveolar 
damage, thrombosis, and haemophagocytosis (Hanley et al. 2020). However, further studies are warranted to understand these potential parainfectious processes affecting COVID-19 patients, apart from the direct cytopathic CNS damage caused by SARS-CoV2.

\section{Probable routes of SARS-CoV2 entry into the CNS}

Previous studies have shown that $\mathrm{H}-\mathrm{CoV}$ s can invade the CNS transynaptically under still indeterminate circumstances. Infection of SARS-CoV has been reported in the brains of both patients and experimental animals, where the brainstem was heavily infected (Glass et al. 2004; Gu et al. 2005; Netland et al. 2008). Likewise, some other coronaviruses are also known to spread via synaptically connected routes to the medullary cardiorespiratory center from the mechanoreceptors and chemoreceptors in the lung and lower respiratory airways (Bernstein et al. 2018; Hadziefendic and Haxhiu 1999; Kalia and Mesulam 1980; Li et al. 2012). SARS-CoV and OC43 infection in a mice model established that it potentially spreads trans-axonally from the nose to olfactory neurons to the olfactory bulb and other brain areas, including the cardiorespiratory center, and brainstem (Dubé et al. 2018; Netland et al. 2008). Taking hints from all previously identified $\mathrm{H}-\mathrm{CoVs}$, it is postulated that SARS-CoV2 can follow three distinct routes. One of the most common routes is from nasal epithelium to the bronchi and the lower respiratory tract, as mentioned previously. Like OC43 and SARS-CoV, SARS$\mathrm{CoV} 2$ can also follow a retrograde axonal transport via olfactory bulb and get direct access to the brain parenchyma (Dubé et al. 2018; Netland et al. 2008). There is also a possibility of transport from the lungs to the brainstem and then to the spinal cord via the lung-brain axis (via cranial nerves), given the high innervation of lungs ( $\mathrm{Li}$ et al. 2012). In fact, a very recent autopsy study immunohistochemically showed that SARS-CoV2 spike and nucleocapsid proteins were present in medulla oblongata and the cranial nerves originating from the brainstem (Matschke et al. 2020). This warrants the further understanding of the lung-brain axis as a route of SARS-CoV2 transmission. Moreover, some studies suggest that SARS-CoV2 can also follow an enteric route through the parasympathetic vagus nerve, taking insights from hemagglutinating encephalomyelitis virus (HEV) (Andries and Pensaert 1980). SARS-CoV2 can also enter the CNS upon viremia (Tseng et al. 2007), breaching the blood-brain barrier (BBB) by directly infecting ACE-2 receptor-containing brain vascular endothelial cells (Choi et al. 2020; Varga et al. 2020). It can also use the circulating leucocytes as vectors (Trojan horse) to enter the CNS upon BBB damage, as seen in SARSCoV infection (Gu et al. 2005) (Fig. 1).

\section{m-CoV MHV infection provides an ideal experimental animal model for neuro-COVID-19}

Similar to H-CoVs, after intranasal infection, MHV too can either travel to the periphery or can travel from neuron to neuron via olfactory nerves, up to the olfactory bulb from where it spreads across the brain and eventually goes to the spinal cord (Perlman et al. 1989), There are three very commonly used neurotropic strains of MHV. MHVJHM is a highly virulent neurotropic strain that can cause severe encephalitis and demyelination but cannot infect the liver (Bergmann et al. 2006; Fleming et al. 1986). MHV-A59 is a dual hepato-neurotropic strain of MHV which induces acute hepatitis, meningoencephalomyelitis, optic neuritis, and persistent infection in the CNS with characteristic chronic progressive demyelination and axonal loss, which is instrumental in understanding the mechanism of human neurological disease Multiple sclerosis (MS) (Dandekar et al. 2001; Das Sarma 2010; Das Sarma et al. 2000; Lavi et al. 1984b; Shindler et al. 2008). MHV-A59 is denoted as the demyelinating (DM) strain of MHV. MHV-2, another closely related strain to MHV-A59, can cause hepatitis with a limited ability to invade CNS, which can only induce meningitis without encephalitis, myelitis demyelination (Das Sarma 2010; Sarma et al. 2001). The disease outcome and degree of infection variably depend on numerous factors like age and strain of the mice, the strain of the virus, virulence of the virus, and even the route of inoculation. Some strains of MHV are highly virulent, while others exert mild but persistent disease symptoms. It thus provides a platform to decipher the cause-effect relationship in an experimental animal model to analyze the neurological disease progression, correlating with the viral titer kinetics.

\section{Comparative study of isogenic recombinant strains of MHV-A59: a tool to understand viral-induced neuroinflammatory demyelination}

The comparative neuropathological studies between parental MHV-A59 and its isogenic spike recombinant strain, RSA59, in comparison with parental nondemyelinating (NDM) MHV-2 and its isogenic strain RSMHV2 made a paradigm shift in the understanding of the role of the spike protein in viral antigen spread, cell-tocell fusion, and its associated pathogenesis. RSA59 has the spike from parental DM strain MHV-A59, and RSMHV2 has the spike from the parental NDM MHV-2 strain, in 


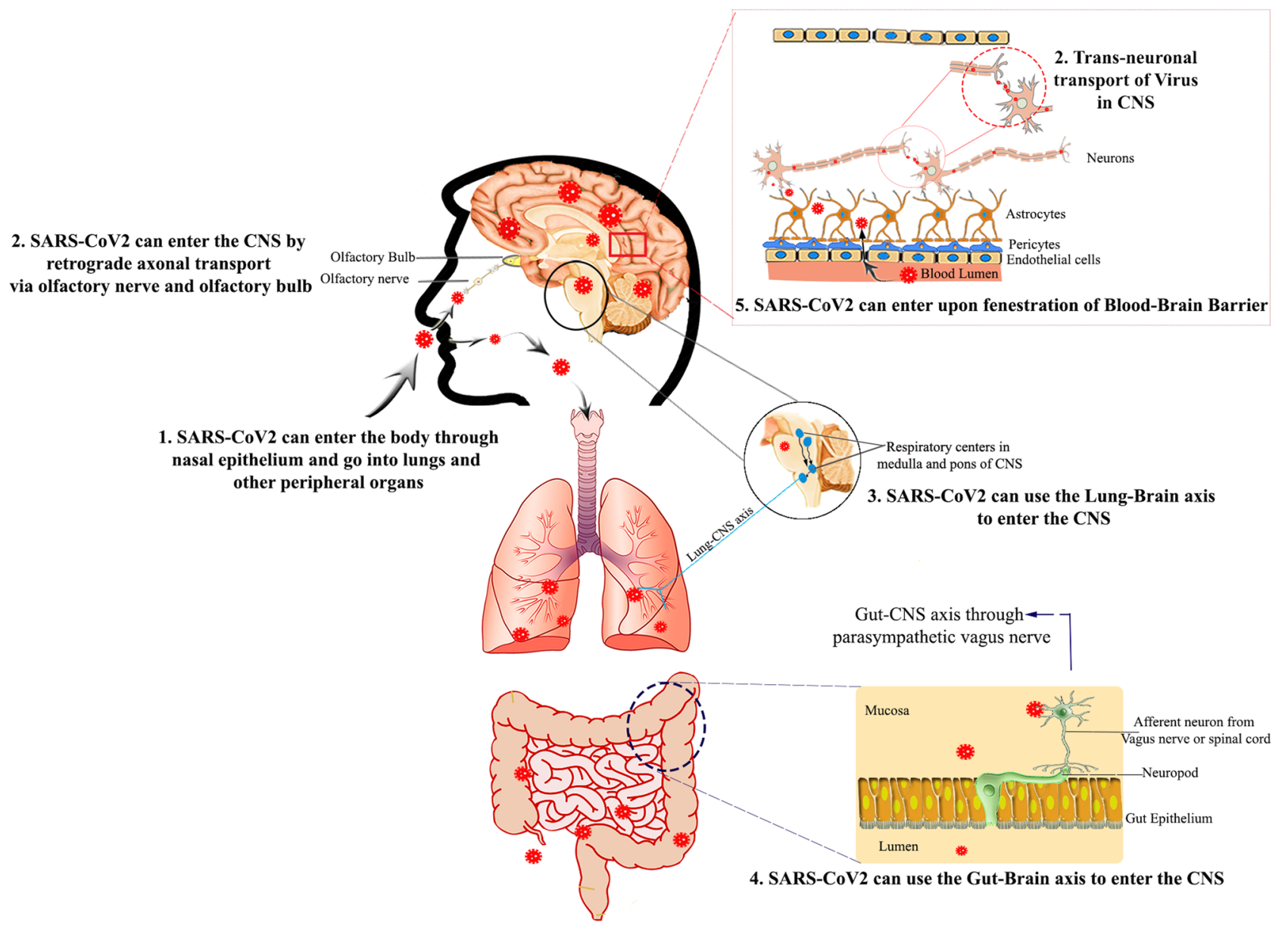

Fig. 1 Probable entry of SARS-CoV2 into CNS: SARS-CoV2 is known to conventionally enter the lungs, through the nasal passage and its cargo to lower respiratory tract and different peritoneal organs (1). However, SARS-CoV2 can also enter the CNS through several probable routes. SARS-CoV2 can enter by retrograde axonal transport through nasal epithelia to the olfactory bulb via olfactory neurons and get direct access to the brain parenchyma by trans- neuronal spread (2). SARS-CoV2 can possibly transport from the lungs to the brainstem and spinal cord via the lung-brain axis (3). Moreover, SARS-CoV2 can also follow an enteric route through gutCNS axis via parasympathetic vagus nerve (4). SARS-CoV2 can also enter the CNS upon viremia and breeching of the blood-brain barrier (BBB) (5) the background of DM MHV-A59 (Fig. 2) (Das Sarma et al. 2002). It also denoted that Spike protein in $\mathrm{m}-\mathrm{CoV}$ may not be the only determinant of viral entry as both the recombinant strains can enter into the CNS and can induce acute phase (days 5-7 p.i.) meningoencephalitis characterized by the accumulation of inflammatory cell positive for leucocyte common antigen (LCA) and CD11b, denoting microglia/monocyte/macrophages (Fig. 2) (Das Sarma et al. 2008). Though, both the strains induce similar acute neuroinflammation, only RSA59 can induce chronic progressive demyelination with a concurrent axonal loss, which peaks at day 30 p.i. (chronic phase of inflammation) (Das Sarma 2010, 2014; Das Sarma et al. 2008, 2009) (Fig. 2).Viral antigen trafficking studies revealed that the induction of demyelination is a multifactorial outcome depending upon the successful axonal transport from the gray to white matter, in both the spinal cord and optic nerve, from the point of inoculation in the brain, and the persistence of the virus in the glial cells of the white matter (Das Sarma et al. 2008; Kenyon et al. 2015; Shindler et al. 2011). From the aspect of genomic control of pathogenic properties, spike protein is one of the primary targets for developing anti-virals, due to the antigenic properties of its S1 domain and the fusogenic properties of the S2 domain. To dissect the minimal essential motif of spike required for the fusogenicity and pathogenicity and to design the potential therapeutic targets, very recent studies, by combining in-silico molecular modeling, NMR studies, in combination with in vitro and in vivo experiments, demonstrated that two consecutive central proline in the fusion peptide of spike protein provides rigidity due to the lack of dihedral fluctuations and is responsible for cell to 
cell fusion and consecutive neuropathogenesis in RSA59 strain infection (Singh et al. 2019). At the same time, by using targeted recombination, the deletion of one proline showed that the mutant strain is impaired in its ability to cause the cell to cell fusion, retrograde axonal transport, consecutive demyelination, and retinal ganglionic cell loss, as a part of virus-induced neurodegeneration (Rout et al. 2020; Singh et al. 2019).

\section{Parallels between m-neuro-COVID and COVID-19}

\section{Innate immunity and delayed interferon responses}

MHVs are weak inducers of IFN $\alpha / \beta$ in vitro and show delayed induction in vivo (Roth-Cross et al. 2007). Upon MHV-A59 infection, astrocytes exhibit delayed but substantially upregulated IFN $\alpha / \beta$ mRNA levels, along with microglia. MHC-I surface expression by microglia coincides with IFN $\alpha / \beta$ expression. MHV-A59 infection in the type 1 interferon receptor-deficient (IFNAR-/-) mice as well as astrocytes deficient in IFNAR induced significantly accelerated the disease course, enhanced infectious viral particles in the CNS, and direct neuron infection with heightened mortality (Cervantes-Barragan et al. 2007; Hwang and Bergmann 2018, 2019). This IFNAR abrogation on astrocytes led to diminished $\mathrm{T}$ cell recruitment into the CNS but enhanced IFN- $\gamma$ production (Hwang and Bergmann 2018). However, despite enhanced levels of IFN$\gamma$, the virus replicated profusely, suggesting that IFN- $\gamma$ is unable to exert its antiviral functions like IFN- $\gamma$-dependent class II transactivator (CIITA) activation of MHC-II expression on microglial cells, leading to diminished $\mathrm{T}$ cell infiltration and damage to neurons by uncontrolled virus replication (Hwang and Bergmann 2019). This emphasizes the dependence of IFN- $\gamma$ on IFN $\alpha / \beta$ production and activation in the CNS. It should also be noted that elevated and sustained levels of IFN $\alpha / \beta$ antagonizes IFN$\gamma$-induced MHC-II based activation of macrophages. This desensitization prevents the toxic IFN mediated cytokine storm as well as detrimental chemokine expression by activating interferon-stimulating genes (ISGs)(Hwang and Bergmann 2019). ISGs act as negative regulators of the signalling cascade, limiting disproportionate immune responses, which may lead to excessive tissue damage (Ivashkiv and Donlin 2014). Therefore, IFN-responses can moderate both protective as well as pathogenic responses, depending on the context of their activation and the crosstalk between IFN $\alpha / \beta$ and IFN- $\gamma$. Some studies also highlighted the direct roles of ISGs. Deficiency of Ifit $2 /$ ISG54 causes uncontrolled MHVA59/RSA59 replication and enhanced encephalitis via impaired IFN $\alpha / \beta$ induction in macrophages (Butchi et al. 2014). Moreover, a very recent study highlighted that Ifit 2 deficiency cause reduced microglia/macrophage activation induces lower levels of CX3CR1 expression on microglia and reduced $\mathrm{CD}^{+}{ }^{+} \mathrm{T}$ and NK T cell infiltration in the CNS (Das Sarma et al. 2020). Drawing a parallel between MHV-A59/RSA59 and previous SARS-CoV infection, it is evident that dysregulated type I interferon and inflammatory monocyte-macrophage responses induce deleterious pneumonia in SARS-CoVinfected mice (Channappanavar et al. 2016). SARS-CoV infection in IFNAR-/- C57BL/6 mice showed higher viral titers (Mordstein et al. 2010).

Mechanistically, both structural and non-structural proteins of MHV have the potential to inhibit RNase L activity, a downstream effect of type I IFN signalling (Ye et al. 2007; Zhao et al. 2013, 2012). MHV-N can exert its IFN-antagonizing function by targeting PACT (a cellular dsRNA-binding protein which binds to RIG-I and MDA5 to induce IFN production) and impairing PACT-RIG-I/MDA5 interactions and RIG-I/MDA5 activation for the downstream IFN production (Ding et al. 2017). A similar mechanism has been observed in SARS-CoV. The nsp1 protein of MHV also plays an important role, interfering with type I IFN response. Similarly, nsp1 proteins of SARS-CoV induce degradation of type 1 interferon mRNA in infected cells, preventing the accumulation of IFN- $\beta$ mRNA, and inhibit type I IFN signalling by reducing STAT1 phosphorylation (Lei et al. 2013). Studies show that MHV does not induce nuclear translocation of IFN- $\beta$ transcription factor interferon regulatory factor 3 (IRF-3) or IFN $\beta$ gene induction, but does not block these pathways either, like SARS-CoV. Experiments advocate that papain-like protease domain 2 (PLP2), a catalytic domain of the nonstructural protein 3 (nsp3) blocks TANK-binding kinase-1 (TBK1) present upstream of IRF3 and also prevents translocation of IRF3 itself to the nucleus (Wang et al. 2011). A very recent study highlighted the importance of highly conserved selective packaging of positive-sense genomic RNA (gRNA) for MHV virulence and immune evasion to prevent sensitization to type I IFN innate immune response (Athmer et al. 2018). A similar phenomenon can be utilized by SARS-CoV2 to evade initial innate immunity.

COVID-19 patient post-mortem lung tissues and serum samples showed undetectable levels for both IFN $\beta$ and the IFN $\gamma$ family of interferons and low ISGs, despite profusely activated proinflammatory cytokines/chemokines (BlancoMelo et al. 2020). A very recent study suggested the presence of auto-antibodies against type 1 IFNs (IFN- $\omega$ and IFN- $\alpha$ ) in the critical cases of COVID-19 (Bastard et al. 2020). A concurrent study reported the genetic loss of function variants at human loci known to govern type 1 IFN immunity in COVID-19 patients (Zhang et al. 2020). Studies suggested that SARS-CoV2 might not be a potent 
a

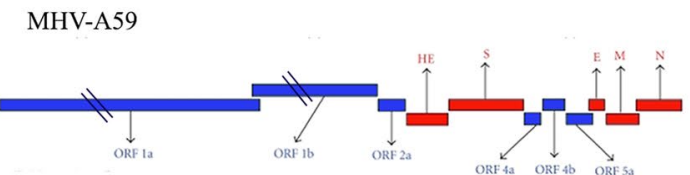

b

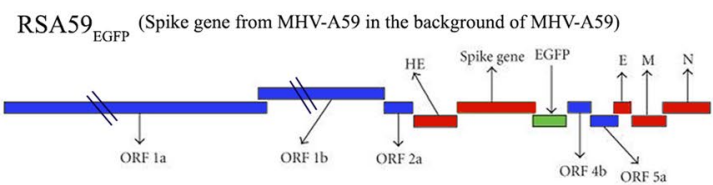

MHV-2

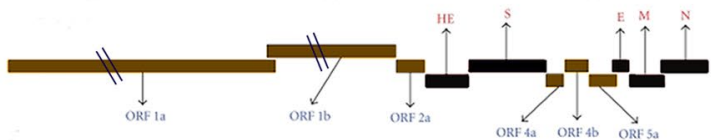

RSMHV- $2_{\text {EGPP }}$ (Spike gene from MHV-2 in the background of MHV-A59)

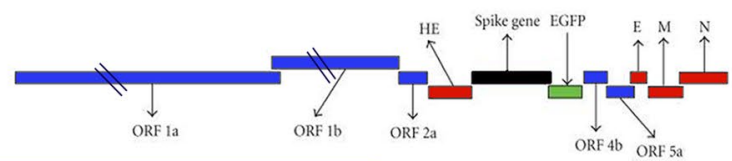

C

\begin{tabular}{|c|c|c|c|c|}
\hline & MHV-A59 & MHV-2 & RSA59 & RSMHV2 \\
\hline Meningitis & Positive & Positive & Positive & Positive \\
\hline Encephalitis & Positive & Negative & Positive & Positive \\
\hline Myelitis & Positive & Negative & Positive & Negative \\
\hline Optic Neuritis & Positive & Negative & Positive & Negative \\
\hline Demyelination & Positive & Negative & Positive & Negative \\
\hline Axonal Loss & Positive & Negative & Positive & Negative \\
\hline $\begin{array}{l}\text { Optic nerve } \\
\text { demyelination }\end{array}$ & Positive & Negative & Positive & Negative \\
\hline
\end{tabular}

d

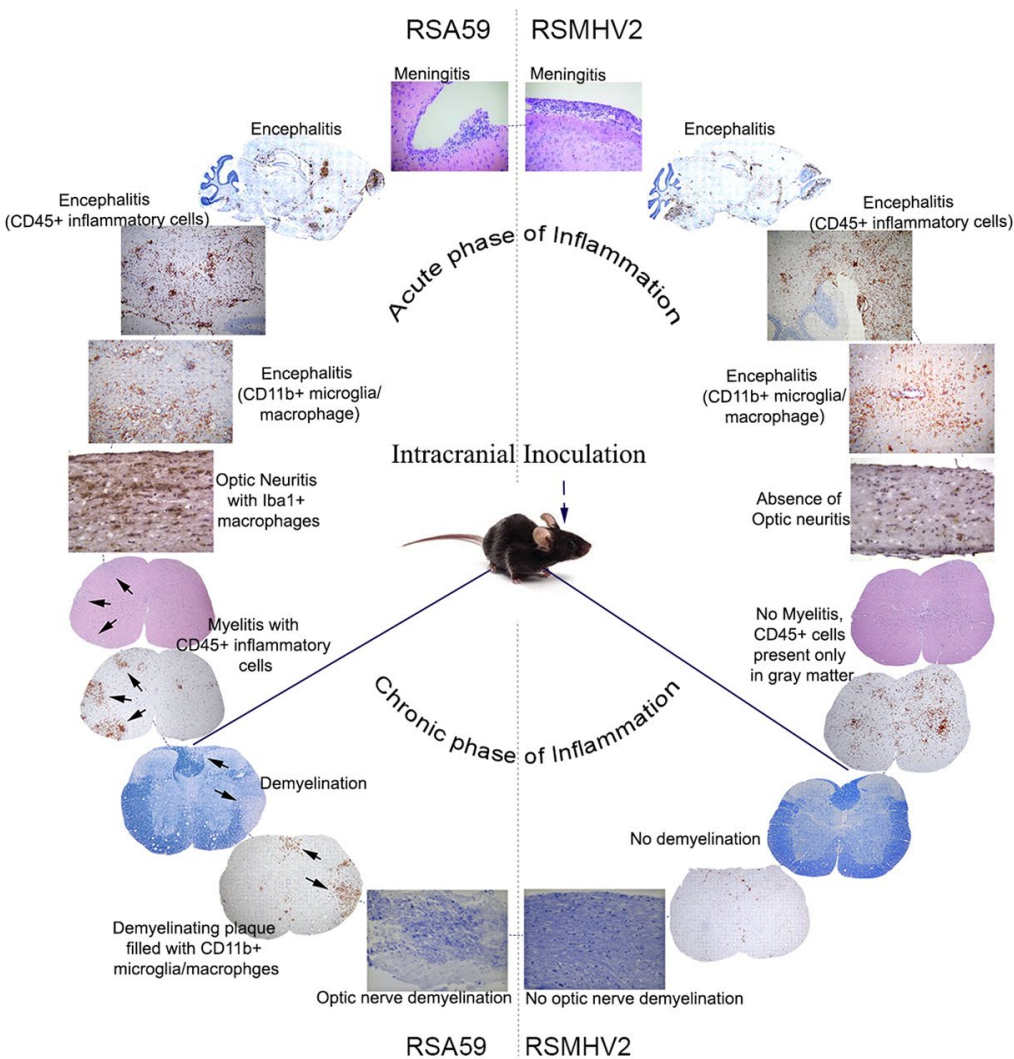

inducer of IFN response at a low multiplicity of infection (MOI), but high MOI infections with robust replication could detect IFN-I and -III signatures (Blanco-Melo et al. 2020). Thus, IFN response may be directly proportional to the viral load. In another study, RNA-sequence analysis of inflammatory monocyte-derived macrophages (IMMs) in the bronchoalveolar fluid (BALF) of severely ill COVID-19 patients prompted strong interferon gene signatures, suggesting that initial interferon signatures may be protective; however, persistent IFN-gamma signalling may propagate untimely and excessive macrophage activation (Liao et al. 2020). Together these studies suggest that a compromised IFN response at the beginning of infection leads to unrestrained CoV2 replication and its systemic 
४Fig. 2 Overview of comparative neuropathology of parental and spike protein recombinant strains of $\mathrm{m}-\mathrm{CoV}$ (neurotropic and demyelinating MHV-A59 and non-neurotropic MHV-2) Panel a depicts the line diagram of structural and non-structural proteins of parental MHV-A59 and MHV-2. Panel b depicts the spike protein exchange between MHV-A59 and MHV-2 in the background of MHV-A59. Heterologous recombination replaced Orf $4 a$ and part of $4 b$ with EGFP. These EGFP inserted recombinant strains are denoted as RSA59 and RSMHV2. Panel c summarizes the differential neuropathological outcome of parental (MHV-A59/MHV-2), and spike protein recombinant (RSA59/RSMHV2) strains upon intracranial infection in C57BL/6 mice. The differential outcome of RSA59 and RSMHV2 infection summarized in panel $\mathbf{c}$ is pictorially presented with histopathological evidence, including gross morphology stained with hematoxylin and eosin (H\&E), inflammatory cells stained with LCA and CD11b and myelin with LFB in panel d. Panel d represents that RSA59 and RSMHV2 both can enter the brain parenchyma and induce encephalitis, perivascular cuffing, and microglial nodule formation (denoted by LCA and CD11b staining). While RSA59 can reach the optic nerve by retrograde axonal transport and induce optic neuritis (evident by Iba1 staining), RSMHV2 is impaired in retrograde axonal transport and show limited (if any) optic nerve inflammation. RSA59 can induce myelitis, with the accumulation of LCA positive cells majorly in the white matter during acute inflammation, whereas RSMHV2 showed insignificant accumulation of inflammatory infiltrates in white matter but profuse inflammation in gray matter. Most strikingly, RSMHV2, despite inducing acute phase encephalitis like RSA59, is unable to induce demyelination neither in the spinal cord nor optic nerve during the chronic phase of inflammation. In contrast, RSA59 can induce profuse myelin loss with accumula-

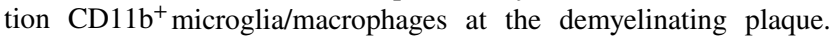
Original images obtained from (Das Sarma et al. 2008, 2009; Das Sarma 2010; Shindler et al. 2011) On another note, the replacement of the A59 spike gene with the spike of neurovirulent strain of MHVJHM, JHM.SD in A59 background ( $\mathrm{rA5} / \mathrm{S}_{\mathrm{JHM}}$ ) induces high neurovirulence by the recombinant strain infection, which is otherwise isogenic in nature (Navas and Weiss 2003; Phillips et al. 1999), reemphasizing the role of spike protein in neurovirulence.

dissemination, while overt interferon response at the later stages may also lead to a dysregulated immune system.

\section{Differential cellular responses and cytokine/ chemokine responses induced by mild but persistent infection of $\mathrm{m}$-CoV RSA59: understanding the mild-moderate cases of COVID-19 and role of virus persistence}

\section{Neuro-innate inflammation}

The acute stage of MHV-A59 infection in C57BL/6 mice initiates with the activation of brain resident astrocytes and microglia. Type I astrocytes and microglia have been shown to upregulate IL-1 $\alpha$, IL-1 $\beta$, IL2, IL6, IL15, IL13, IL17, all three interferons, and TNF, in vitro (Lavi and Cong 2020). Chemokines are known to recruit neutrophils (CXCL1), monocytes, and natural killer cells (CCL2, CCL5), and lymphocytes $\mathrm{CD}^{+} / \mathrm{CD} 8^{+} \mathrm{T}$ (CXCL9, CXCL10, and CCL5), are secreted initially by activated astrocytes and microglia
(Hosking and Lane 2010). Peripheral leukocyte recruitment begins as early as day 3 p.i., beginning with the cells of the innate immune response, predominantly myeloid cells, such as neutrophils and monocytes/macrophages. Lymphoid cells like CD4, CD8, and natural killer T (NK-T) cells start to enter the CNS from day 5 p.i., coinciding with the peak of viral titer, and hits the maxima at day $7 \mathrm{p} . \mathrm{i}$, in coordination with declining viral titer. While $\mathrm{CD} 8^{+} \mathrm{T}$ cells begin to disappear as early as day 10 p.i. and NK T cells reduce in number, a significant number of $\mathrm{CD}^{+} \mathrm{T}$ cells are present in the inflamed brain even on day 16 p.i.(Chakravarty et al. 2020). Recent Affymetrix microarray analysis of the spinal cords of both RSA59 and RSMHV2 showed elevated expression of inflammatory mediators and innate immune responses. RSA59 is associated with the pronounced activation of microglia, as evidenced by characteristic changes in cellular morphology and increased expression of microglia-specific Iba1 (ionized calcium-binding adaptor molecule involved in GTPase-dependent membrane ruffling and phagocytosis). mRNA expression revealed upregulation of inflammatory mediators known to be released by activated microglia, including chemokines CXCL10, CXCL1, CXCL9, CCL3, CX3CR1, CCL5, and CCL12 along with robust upregulation of proinflammatory markers like IL-6, IL-1 $\beta$, IL-12, IL-15, TNF- $\alpha$, IFN- $\gamma$, and IL-10 (Chatterjee et al. 2014). There was a radical upregulation of CD68, CD74, and CD52, which are cell surface markers for monocyte/macrophage/ microglia. Interestingly, conventional T cells (CD4, CD8) and $\mathrm{B}$ cell transcripts showed insignificant upregulation at the acute phase (Chatterjee et al. 2014). Thus, activated microglia/macrophages at the acute stage can contribute to a local CNS microenvironment that eventually regulates viral replication and IFN- $\beta$ production during the acute phase by managing the infiltration of peripheral lymphoid cells. Expression of adaptive immune response genes showed prominent upregulation only during the chronic phase (Biswas et al. 2016). A recent study of RSA59 infection in CD4-/- mice showed that acute stage hepatitis and meningoencephalomyelitis are not altered in the absence of $\mathrm{CD} 4^{+} \mathrm{T}$ cells, suggesting that mounting initial inflammation is independent of $\mathrm{CD} 4^{+} \mathrm{T}$ cells. However, the loss of $\mathrm{CD} 4^{+} \mathrm{T}$ cells caused acute poliomyelitis (gray matter inflammation) and dorsal root ganglionic (DRG) inflammation, which is rarely observed in wildtype mice at the acute phase (Chakravarty et al. 2020).

It was interesting to note that there was significantly reduced

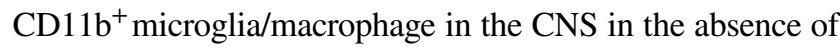
$\mathrm{CD} 4^{+} \mathrm{T}$ cells at the acute phase of RSA59 infection. There was a parallel reduction in chemokine CCL5 or RANTES expression, suggesting that the lower numbers of $\mathrm{CD} 11 \mathrm{~b}^{+}$cells might be the result of dampened infiltration of monocytes/macrophages in the absence of synchronization by $\mathrm{CD} 4^{+} \mathrm{T}$ cells (Chakravarty et al. 2020). Thus, $\mathrm{T}$ lymphocytes and microglia/macrophages 
reciprocally regulate each other and are critical for protection against MHV infection.

\section{Bridging of the innate and adaptive immune system in neuroinflammatory demyelination}

Upon RSA59 infection, as the infectious viral titer goes down beyond the detection limit after day 10 p.i., and the virus replication is controlled, the number of effector inflammatory cells also decrease; however, viral mRNA persists (Das Sarma 2010, 2014; Das Sarma et al. 2002; Lavi et al. 1984a). Such persistent infection in mice contributes to demyelination, which is characterized clinically in the form of partial-to-complete hind-limb paralysis and histopathologically by the loss of myelin sheath as observed with Luxol Fast Blue staining (Das Sarma et al. 2009). The amalgamation of spike mediated transsynapticaxonal transport of RSA59 resulting in evasion of the aggressive immune system, its ability to infect the white matter oligodendrocytes, and its persistence in the white matter are the key checkpoints for the chronic progression demyelination, axonal loss, and optic nerve demyelination, as discussed previously (Das Sarma 2010; Kenyon et al. 2015; Shindler et al. 2011; Singh et al. 2019).

While the viral spread is critical, host immune activation also plays a prominent part. RSA59 infection is also represented with the accumulation of $\mathrm{CD} 11 \mathrm{~b}^{+}$/ $\mathrm{Iba} 1^{+}$microglia/macrophages filled with myelin debris within the demyelinating plaques at the chronic phase of inflammation (Das Sarma et al. 2009). High-resolution TEM microscopy demonstrated direct contact of the macrophage cell membrane with the outer myelin sheath and multiple vacuoles at the inner myelin lining. Axon was completely intact, but the myelin was lifted apart from the axon fiber, as if the microglia/macrophages were stripping off the myelin sheath (Das Sarma 2014; Das Sarma et al. 2009). This suggests that virus replication, viral tropism, viral spread, and host immune responses together mediate the myelin destruction.

A recent study highlighted the critical axis of microglia/ macrophage and $\mathrm{CD} 4^{+} \mathrm{T}$ cells in ameliorating demyelination. RSA59 infection in CD4-/- mice showed elevated microglia/ macrophage activation at the chronic stage of inflammation. Characteristic axon blebbing pathology was observed in the brains of infected CD4-/- mice, where the neuropil showed inflammation and vacuolation with aggravated microglia/macrophage accumulation at the demyelinating plaque (Chakravarty et al. 2020). These microglia/ macrophages were of M2 phenotype (anti-inflammatory), attempting to control the prolonged viral persistence and restore homeostasis to prevent further tissue damage, but failed without the help of $\mathrm{CD} 4^{+} \mathrm{T}$ cells. M2 microglia/ macrophages also present high phagocytic ability. Their activation and persistence, therefore, accentuate the direct myelin stripping, leading to significantly exacerbated demyelination and axonal loss in CD4-/- mice (Chakravarty et al. 2020).

Thus, to re-iterate, RSA59-induced neuroinflammation is initiated primarily by the activation of CNS resident immune cells like astrocytes and microglia, which set the stage for innate immune inflammation. However, it requires help from the adaptive branch of the immune system, notably $\mathrm{CD} 4^{+} \mathrm{T}$ cells, to restore the homeostasis by balancing the proinflammatory milieu and switching the microglial activation to an anti-inflammatory state at the chronic stage of inflammation. $\mathrm{CD} 4^{+} \mathrm{T}$ cells thus act as a bridge between the innate and adaptive immune systems and provide help in the activation of classical humoral immunity.

\section{Humoral immunity}

While the acute phase of infection is independent of humoral immunity, the chronic demyelinating phase of MHV infection requires antibody-secreting cells (ASCs) to prevent re-emergence of the virus (Bergmann et al. 2006). RSA59 infection, and not RSMHV2 infection, uniquely induces tenfold upregulation of immunoglobulins like IgmRNAs like Ighg3, IGJ, Igk-V28, and Igkv4 at the chronic phase of infection via B cell activation (Biswas et al. 2016).

In summary, utilizing RSA59 infection of the CNS as a model of virus-induced encephalomyelitis with chronic progressive demyelination and concurrent axonal loss has provided substantial experimental evidence to understand the nexus between the cellular and molecular components of the two arms of host immunity: the innate and adaptive immune responses, along with the interplay of cytokines and chemokines responsible for the cellular recruitment, activation, and antiviral activity. Thus, RSA59/RSMHV2 infection is a model of a protective regulated inflammation where viral replication is controlled with the help of CNS resident microglia in orchestration with infiltrating monocyte/macrophages and optimally activated T-lymphocytes, along with regulated cytokine and chemokine secretion. This model thus depicts the balanced scenario of host survival with or without chronic progressive disease. Very recent studies identified the presence of biomarkers like GFAP (Glial Fibrillary acidic protein, present in astrocytes) in the plasma of mild-moderate SARS-CoV2 patients, and NfL (neurofilament light chain protein, present in neuronal outgrowths) in the blood plasma of critically ill patients requiring ventilation, possibly reflecting a phenomenon of early astrocytic/glial activation and more delayed axonal/neuronal damage, similar to MHVA59/RSA59 neuroinflammation (Kanberg et al. 2020). Furthermore, a current study also found microglial activation and $\mathrm{CD}^{+} \mathrm{T}$ cell infiltration in the autopic brains of patients 
with COVID-19 symptoms (Matschke et al. 2020). However, the complex pathophysiology of COVID-19 in the brain is yet to be completely unravelled.

\section{Insights gained from a highly neurovirulent strain of $\mathrm{m}$-CoV, MHV-JHM, to explain the critical cases of COVID-19}

In contrast to the moderate but persistent infection and neuroinflammation induced by RSA59, the highly neurovirulent JHM.SD infection depicts a system with robust virus replication, profuse cytokine/chemokine storm, but suboptimal CD4 and CD8 response, leading to highly severe disease pathology, and results in death (Bender and Weiss 2010; Rempel et al. 2004).

Lethal JHM.SD infection causes prolonged innate immune responses with high IFN- $\beta$ production that goes beyond day 5 p.i. and robust upregulation of proinflammatory cytokines and chemokines like IL-6, IL- $1 \alpha$, IL-1 $\beta$, IL-12, CCL3, CCL4, CCL5/RANTES, CXCL10, TNF- $\alpha$, and macrophage chemoattractants like macrophage inflammatory proteins (MIP1 and MIP2) (Bergmann et al. 2006; Liu and Lane 2001; Rempel et al. 2004). This profound cytokine storm leads to enhanced chemotaxis of innate immune cells like neutrophils, macrophages, and natural killer (NK) cells into the CNS and leads to the destruction of the brain parenchyma. It should be noted that neurovirulence directly reciprocates to the magnitude of immune response and the levels of cytokines/chemokines induction. JHM.SD shows higher proinflammatory cytokines, massive macrophage/ microglia accumulation, and lower IFN- $\gamma$ as compared to with MHV-A59 infection (Rempel et al. 2004). Along with profuse innate immunity, JHM.SD also showed reduced T cell responses and concomitant IFN- $\gamma$ levels (Rempel et al. 2004). Using the targeted recombination system, it was clearly shown that macrophage chemoattractant expression levels were influenced by spike gene and thus were more for the chimeric $\mathrm{rA59} / \mathrm{S}_{\mathrm{JHM}}$ (inserting JHM.SD spike in A59 background). However, it was interesting to note that $\mathrm{T}$ cell infiltrating chemokines like CXCL9 and CXCL10 and subsequent responses were higher in the isogenic recombinant strain developed by inserting A59 spike in JHM.SD background (rJHM/S $\left.\mathrm{S}_{\mathrm{A} 59}\right)$. Also, these $\mathrm{rA5} / \mathrm{S}_{\mathrm{JHM}}$ chimeric mice exhibited profuse viral spread like JHM. $\mathrm{SD}$ but showed robust upregulation of $\mathrm{CD} 8^{+}$response like A59, and survival enhanced (Bender and Weiss 2010; Phillips et al. 2002), suggesting that $T$ cell responses can be coordinated by other background genes, rather than spike only. Though $\mathrm{CD} 4^{+} \mathrm{T}$ cells are required for adequate viral clearance, they have also been shown to exhibit a pathogenic role during acute MHV.JHM infection. Mutation in one of the MHC-II epitope M133 of highly virulent JHMV strain is shown to reduce the mortality from $100 \%$ to 0 at day $7 \mathrm{p.i}$ (Anghelina et al. 2009).

While JHM.SD infection cannot explain the chronic phase of the disease due to high mortality, attenuated variant of MHV-JHM, 2.2-V-1 is used to understand the role of $\mathrm{T}$ cell response. Similar to the conventional strain of MHV-A59/RSA59 intracranial inoculation of mice, 2.2-V-1 induces activation and expression of CXCL9 and CXCL 10 by CNS resident astrocytes and microglia (Lane and Hosking 2010; Phares et al. 2013). However, in contrast to MHV-A59, which initiates with the activation of microglia/macrophages first and which later paves the way for activated $\mathrm{T}$ cells to take charge of the immune response (by day 5-7), 2.2-V-1 also activates virus-specific CD8 T cells in the cervical lymph nodes as early as day 3 p.i. (which was absent upon JHM.SD infection)(Marten et al. 2003). $\mathrm{CD}^{+} \mathrm{T}$ cells start accumulating in the brain by day 5 p.i., reaching the peak ay day 7 p.i (Marten et al. 2003). These virus-specific CD $8^{+} \mathrm{T}$ cells secrete IFN- $\gamma$, produce granzyme, and induce cytolysis mediated viral clearance. Perforin-mediated cytolysis eliminates MHV from astrocytes and microglia, and IFN- $\gamma$ prevents MHV replication within oligodendroglia in vivo (González et al. 2006; Lin et al. 1997). Cytokine and Chemokine transcripts detected at the initial include IL-6, IL-10, IL-1 $\alpha$, IL-1 $\beta$, IL-12, CXCL10, CXCL9, MCP-1, MCP-3, MIP- $1 \alpha$, MIP-1 $\beta$, and RANTES (CCL5), CXCR3, CCR1, CCR2, and CCR5. Studies show that neutralization of CCL5, CXCL9, and CXCL10 during the acute stage of infection leads to augmented viral replication and decreased infiltration of $\mathrm{CD}^{+}$and $\mathrm{CD} 8^{+} \mathrm{T}$ cells in the CNS (Lane and Hosking 2010). As the virus gets cleared by day 12 p.i., the number of $\mathrm{CD}^{+} \mathrm{T}$ cells decline, and $\mathrm{CD} 8^{+} \mathrm{T}$ cell loses its cytolytic activity. $\mathrm{CD} 4^{+} \mathrm{T}$ cells play direct roles of secreting high levels of IFN $\gamma$ and upregulating MHC-II on the antigen-presenting cells (APCs), as well as supporting roles like preventing $\mathrm{CD} 8^{+} \mathrm{T}$ cell apoptosis and regulate their infiltration into the CNS parenchyma, during the acute stage of infection (Bergmann et al. 2006; Lane and Hosking 2010).

Mice that survive the acute phase of infection develops a chronic immune-mediated demyelinating disease, as a result of virus persistence (Perlman et al. 1990). Both $\mathrm{CD}^{+}{ }^{+}$and $\mathrm{CD} 8^{+}$cells play important roles in the induction of demyelination. They have redundant but unidentical roles in MHV-JHM induced demyelination. MHV-JHM (V5A13.1) infection showed a significant reduction in the severity of demyelination in CD4-/- mice as compared to both CD8/- and wildtype mice with concurrent decreased levels of RANTES/CCL5, i.e., reduced microglia/macrophage infiltration (Lane et al. 2000). Adoptive transfer of $\mathrm{CD} 4{ }^{+} \mathrm{T}$ in MHV-JHM-infected RAG1-/- resulted in more severe clinical disease, but less demyelination whereas $\mathrm{CD} 8^{+} \mathrm{T}$ 


\section{Mild-Moderate COVID-19}

Acute phase of inflammation Chronic phase of inflammation

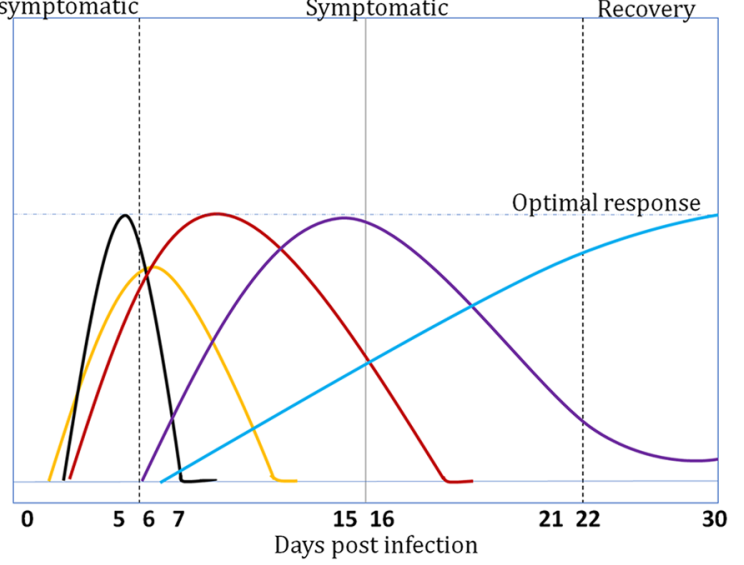

Mild-Moderate COVID-19

Protective-regulated inflammation

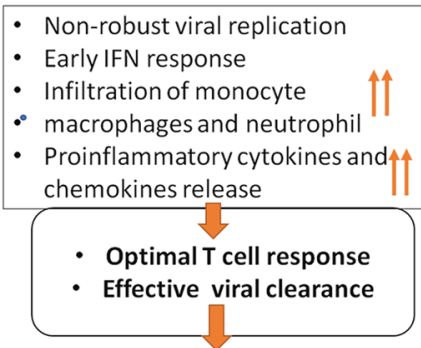

Protective immunity

Host survival with or without chronic progressive disease

MHV-A59/RSA59 induced neuroinflammation Acute phase of inflammation Chronic phase of inflammation

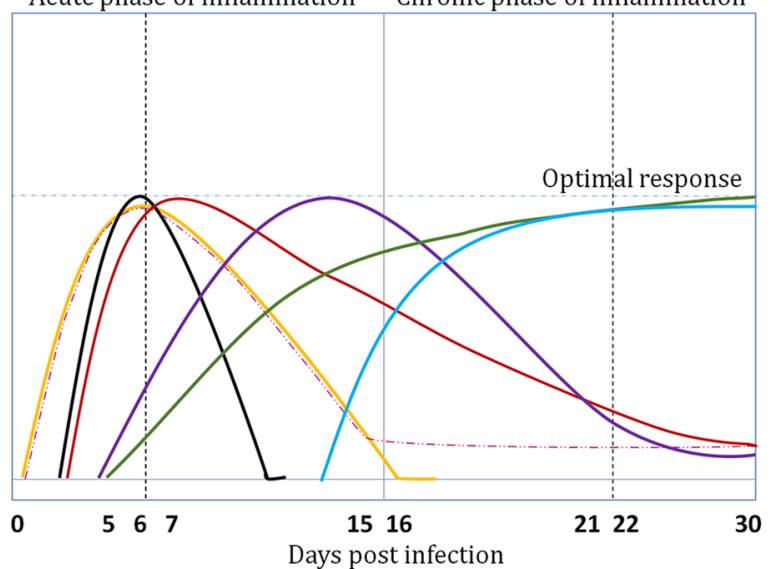

Severe COVID-19

Acute phase of inflammation Chronic phase of inflammation

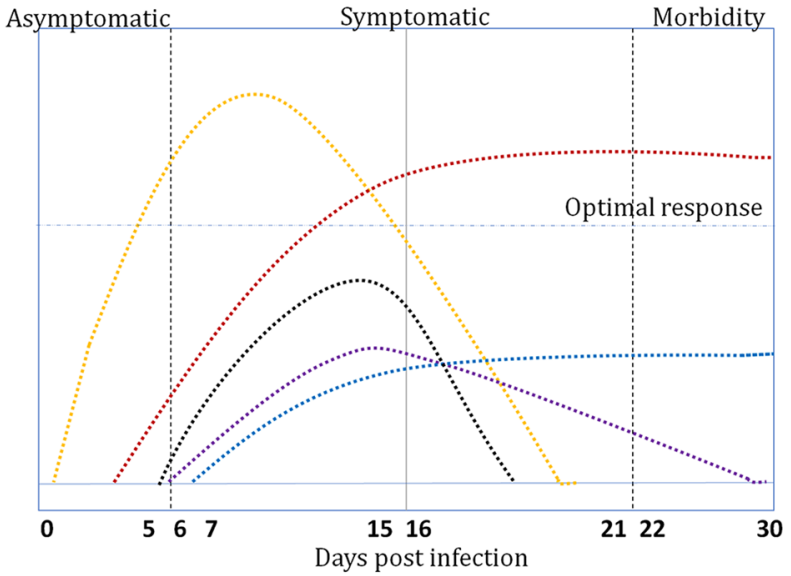

Severe COVID-19

Pathogenic-Dysregulated inflammation

Robust viral replication

- Delayed IFN response

- Infiltration of monocyte-

macrophages and neutrophil |||

- Proinflammatory cytokines and

chemokines release

- Sub-Optimal T cell response due to lymphocytopenia

- Impaired viral clearance response

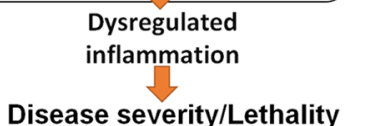

Virus Replication IFN response Innate Immune activation Adaptive T cell activation Humoral response Demyelination Viral RNA

MHV-JHM (JHM.SD) induced neuroinflammation Acute phase of inflammation Chronic phase of inflammation

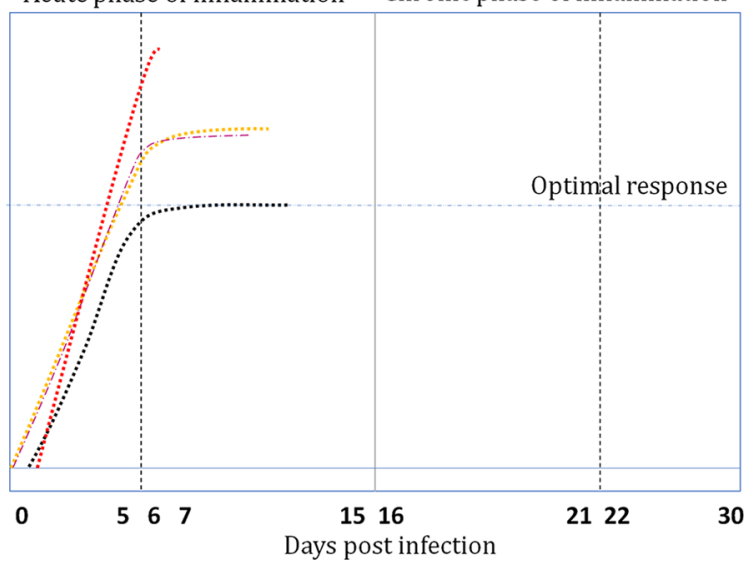


4Fig. 3 Parallel Schematic representation of protective-regulated inflammation vs Pathogenic-dysregulated inflammation in COVID19 and murine coronavirus induced neuroinflammation. Panel A is a line graph depiction of time kinetics of the severity of the COVID19 disease process. $X$-axis shows approximate days of post-infection based on clinical symptoms. Days 0-5 depict the asymptomatic stage of COVID-19; approximately overlapping days 5-20 signify the symptomatic stage of COVID-19, followed by recovery or morbidity, depending on the severity of the disease. Based on the case-reports, different lines demonstrate viral replication (yellow), IFN response (black), innate immune activation (red), adaptive $\mathrm{T}$ cell activation (violet), and humoral responses (blue). Solid line in the left panel depicts the mild-moderate COVID-19 disease course, followed by recovery, whereas dotted lines in the right panel depict the scenario of severe COVID-19 disease course, leading to morbidity. Panel $\mathbf{b}$ is a flow chart to describe the cause-effect relationship of protectiveregulated inflammation, and pathogenic-dysregulated inflammation, parallel to the individual line-graphs depicted in Panel a. Panel c (left panel) is a line-graph depiction of the time-kinetics of the differential acute mild-to-moderate neuroinflammation induced by MHV-A59/ RSA59, similar to mild-moderate symptoms of COVID-19. MHVA59/RSA59 also induces chronic progressive demyelination as early as days 5-6 p.i, which reaches its peak in the spinal cord at day 30 p.i. By day 10 p.i., inflammation resolves in the brain, virus particles get cleared from the system, but viral RNA persists. Panel c (right panel) depicts the acute severe neuroinflammation leading to morbidity or death by highly neurovirulent MHV-JHM.SD, like severe symptoms of COVID-19. Like panel a, different lines demonstrate viral replication (yellow), IFN response (black), innate immune activation (red), adaptive $\mathrm{T}$ cell activation (violet), and humoral responses (blue), and demyelination (green). Solid line in the left panel depicts the MHVA59/RSA59 acute neuroinflammation to chronic progressive demyelination peaking at day 30 post-infection (p.i.), whereas dotted lines in the right panel depict JHM.SD disease course followed by morbidity around days $7-10 \mathrm{p.i}$

cell transfer caused delayed disease course with extensive demyelination. 2.2-V-1 control required both $\mathrm{CD}^{+}$and $\mathrm{CD}^{+} \mathrm{T}$ cells ( $\mathrm{Wu}$ et al. 2000). CD4 T cells thus play both protective and pathogenic roles in the neuroinflammatory demyelination, depending on the strain of the virus and the background of mice, as evident by the strain specific differential action of T cells in MHV-A59 and MHV-JHM. Other studies reveal the importance of IFN $\gamma$ regulation. IFN $\gamma$ is majorly secreted by $\mathrm{CD}^{+}{ }^{+} \mathrm{T}$ cells than $\mathrm{CD} 8^{+} \mathrm{T}$ cells. RAG-/- mice that receive IFN $\gamma-/-\mathrm{CD}^{+} \mathrm{T}$ cells exhibit higher demyelination, whereas IFN $\gamma-/-\mathrm{CD}^{+} \mathrm{T}$ cells transfer in RAG-/- mice induces less demyelination (Savarin and Bergmann 2018). The absence of IFN $\gamma$ hampers virus control by downregulating MHC-class I on oligodendrocytes, prohibiting CIITA activation of MHC-II expression on microglial cells, delimiting neutrophils infiltration and pathogenic Th17 cell activation. Therefore, a fine-tuning of the source and production of IFN $\gamma$ might be critical in determining the fate of chronic progressive demyelination (Savarin and Bergmann 2018). It has been interesting to observe that in the absence of antiinflammatory cytokine IL-10, the severity of demyelination significantly enhances without alteration in the levels of initial viral clearance and even persistent virus, upon neuroattenuated 2.2-V-1 infection. Increased demyelination in IL-10-/- mice is correlated with sustained microglial activation and impaired glial scar formation. Thus, a lack of anti-inflammatory activity can exacerbate tissue damage, independent of acute infection or viral clearance (Savarin and Bergmann 2018).

Hence, by analyzing the differential outcome of infection with specific strains of MHV (MHV-RSA59 and MHVJHM (JHM.SD and 2.2-V-1) and the differential role of inflammatory components in protective v/s pathogenic consequences, this comprehensive review aims to explain the differential signs, symptoms, and severity of the patients suffering from COVID-19.

\section{Knowledge of $\mathrm{m}$-CoV cytokine storm corresponds to systemic SARS-CoV2 dysregulated immune activation and cytokine response}

SARS-CoV2 replication reaches its peak at days 5-6 p.i. and start exerting cytopathic effects (Chu et al. 2020; Zhu et al. 2020). Proinflammatory cytokines and chemokines responsible for extravasation of inflammatory cells to the site of infection like IL- $1 \beta$, IL- 6, IFN $\gamma$, MCP1, IL-10, CXCL10, IL1R $\alpha$, CCL2, CCL7, CCL8, CXCL2, CXCL8, CXCL9, and CXCL16, CXCL17, IL-2alpha, IL-7, IL-10, granulocyte colony-stimulating factor (GM-CSF), macrophage inflammatory protein $1 \alpha$ (MIP1 $\alpha$ ), and tumor necrosis factor (TNF) upregulate in vitro as well as in BALF and blood of the COVID-19 patients, along with inflammatory markers like C-reactive proteins, ferritin, and D-dimers (Blanco-Melo et al. 2020; Coperchini et al. 2020; Huang et al. 2020; Ziegler et al. 2020). The magnitude of these cytokines increases with the severity of the disease, exactly comparable to the two strains of neurotropic MHV (MHV-A59 and JHM. $\mathrm{SD})$. Figure 3 compares the differences between mildmoderate vs. severe cases of COVID-19. Moreover, it depicts the immuno-cellular similarities between the mild-moderate cases of COVID-19 and MHV-A59/RSA59 induced neuroinflammation, and simultaneously between severe/critical cases of COVID-19 and disease course of highly neurovirulent JHM.SD. IL-6 secreting CD14 ${ }^{+}$ $\mathrm{CD}_{16}{ }^{+}$inflammatory monocytes and monocyte-derived $\mathrm{FCN}^{+}$peripheral macrophages has been observed to be significantly high in the severely-ill in contrast to the mildmoderately sick patients, which was directly proportional to the viral load (Coperchini et al. 2020; Huang et al. 2020). (Zhou et al. 2020b), (Liao et al. 2020).Intriguingly, SARS-CoV2 nucleocapsid protein has been found in secondary lymphoid IL- $6^{+}$macrophages (Merad and 
Martin 2020), which could be a reflection of macrophages phagocytizing the infected cells or could be due to direct infection of these macrophages. However, further studies are required for validation. The most interesting fact, which is different in SARS-CoV vs. SARS-CoV2, is the expression of IL-10, which has been shown to be decreased in SARS-CoV (Chen and Subbarao 2007), and other coronavirus infections like MHV, but very strikingly increased upon SARS-CoV2 infection. This discrepancy could result from a negative feedback loop orchestrated by the immune cells to counteract the overt IL-6 response, but further studies are necessary to come to a definite conclusion. This hypercytokinaemia, called the "Cytokine storm," establishes a dysregulated immune system, perhaps as a consequence of unhindered viral replication or probably prolonged virus persistence, which further orchestrate an excessive induction of innate immune cells to the site of infection, ensuing global T-cell lymphopenia especially of the CD8 ${ }^{+} \mathrm{T}$ cell subset. in the severely affected patients (Zheng et al. 2020). Post-mortem TUNEL assay suggests increased levels of lymphocyte apoptosis and elevated expression levels of death receptor FAS which may be a result of direct infection/lysis of $\mathrm{T}$ cells by CoV2 or could be caused by phagocytizing macrophage-derived IL-6(Merad and Martin 2020). The $\mathrm{CD} 4{ }^{+}$and $\mathrm{CD} 8^{+} \mathrm{T}$ cells observed within first-week post SARS-CoV2 infection, although less in number, showed high expression of activation markers CD44, CD69, and CD38, along with HLA-DR and CD45RO (Zhou et al. 2020b). Moreover, Th1 cells present in the ICU cases were mainly pathogenic with increased cytokine production, similar to m-CoV JHM.SD. The absolute numbers of B cells were also gradually decreased with increased disease severity (Tay et al. 2020). Overall loss of protective T cell responses and aggravated/ dysregulated response by monocyte/macrophages responses initiate an endless vicious cycle to which the multi-organ system falls prey.

\section{Conclusion}

In summary, from the innate immune inflammation aspect, the cytokine storm with the amplified innate immune responses is primarily responsible for the tissue damage in the lungs and in fact, CNS upon both m-CoV and SARS-CoV-2 infection. In both neurotropic strains of $\mathrm{m}-\mathrm{CoV}$ and SARS-CoV-2, recognition and rapid clearance of pathogens by the innate immune system provide the first line of defense; however, excessive activation of the innate immune system in response to pathogens can lead to pathological inflammatory consequences, like cytokine storm, leading to morbidity and mortality of the m-CoV JHM.SD strain as well as SARS-CoV-2. Identifying the underlying factors that elicit such injurious reactions and devising therapeutics that block such factors would provide a viable therapy against COVID-19. Moreover, high levels of circulating pro-inflammatory cytokines can cause confusion and alteration of consciousness, whereas a weakened $\mathrm{T}$ cell response may be unable to eliminate virus-infected cells in the CNS, causing further neurologic dysfunction. While early immune responses clear the virus and prevent subsequent pathology, it also supports a paradigm where persistently activated cell-mediated immunity enhances the neuropathology, depicted by microglia-mediated myelin stripping in RSA59 induced neuroinflammation. This establishes that neuro-inflammation is a double-edged sword and provides useful clues for hypothesizing SAR-CoV-2 neuro-immune response.

\section{Discussion}

In the COVID-19 pandemic, ARDS, along with neurological dysfunction, poses a significant physical, mental, and socioeconomic burden to humanity. Considerable and thorough studies of the CSF cytokine profile, T cell-microglia response against SARS-CoV-2 in the brain, and postmortem studies, including an autopsy of nervous tissue and muscle tissues, are the necessary paramount tools required urgently to understand the neuropathogenesis of COVID19 better. Further studies are required to elucidate the occurrence and nature of COVID-19-related CNS damage and differentiate the mechanisms between direct virusinfected CNS disorders and consequent immune mediatedCNS damage.

There are chances that the virus may not infect the lower respiratory tract at all, instead may travel to the nervous system and remain latent for a long time and subsequently reactivate when the immune system is suppressed. Therefore, recognizing neurological symptoms associated with SARS-CoV-2 in patients with a mild or asymptomatic respiratory infection is challenging but holds utmost importance.

While traditionally, the receptor's expression profile is one of the significant determinants of cell tropism, it is not true that all cells that express the receptor or even the cells with the highest expression are the primary targets of the CoVs strains. This is epitomized by MHV studies, as MHV strain JHM.SD is highly neurovirulent and cannot replicate in the liver but the receptor CEACAM1a (MHV Receptor) is expressed highly in the liver but at barely detectable levels in neurons (Miura et al. 2008). Though considerable evidence experimentally embodied the regulatory role of Spike protein that impacted tissue tropism and pathogenesis, other back-ground genes, 
including nucleocapsid, membrane and replicase, and accessory genes, are also important determinants of $\mathrm{CoV}$ biology and pathogenesis. Various strains of parental $\mathrm{m}-\mathrm{CoV}$, including MHV-1, MHV-3, MHVA59, and MHV-JHM, with its isogenic recombinant strain made a significant understanding of the assembly of numerous differential pathogenic outcome from diffused alveolar lung damage, thrombosis to hepatitis, epididymitis, acute stage meningoencephalitis with chronic stage demyelination concurrent with axonal loss, and bulbar axonal vacuolation, optic neuritis, and retinal ganglionic cell loss in the experimental animal models. Identification of the disparity of pathogenic sequels of strains of m-CoVs may be instrumental in understanding the differential SARS-CoV-2's manifestations. In this context, our review adds to the present knowledge and current affairs of beta-coronavirus infection and its possible neuroinflammatory demonstration.

Acknowledgments This work has been a collaborative effort for two decades between the Indian Institute of Science Education and Research Kolkata (IISER-K), India; Indian Institute of Sciences (IISc), India; University of Pennsylvania, USA; Thomas Jefferson University, USA and University of Colorado Denver, USA. The authors would like to convey their special gratitude to Dr. Dhriti Chatterjee, Dr. Kaushiki Biswas, Ms. Fareeha Saadi, Dr. Manmeet Singh, Mr. Saurav Saswat Rout, Dr. Rahul Basu, and Mr. Abhishek Bose for their significant contribution towards understanding the immunological, cellular and genomic regulation of $\mathrm{m}-\mathrm{CoV}$ induced neuropathogenesis. The authors would also like to express their gratefulness to Dr. Abhinoy Kishore, Dr. Subhajit Das Sarma, Dr. Afaq Hussain, Ms. Lucky Sarkar, Mr. Soumya Kundu, Mr. Sourodip Sengupta, Ms. Mithila Kamble, Ms. Vaishali Mulchandani, Mr. Saurav, Mr. Safiriyu Abass A, Dr. Mahua Maulik, and Ms. Soma Nag for their immense contribution to the generation of a large volume of work on $\mathrm{m}-\mathrm{CoV}$ research over the years. Authors would like to thank Dr. Kenneth S Shindler, Dr. Lawrence C Kenyon, and Dr. Randall J Cohrs for their long-standing collaboration on m-CoV research.

Authors' contributions This review was conceptualized by JDS. Literature survey was conducted by DC, in consultation with JDS, correlating $\beta$-coronavirus pathophysiology with special emphasis on SARS-CoV2, MHV-A59, and MHV-JHM and their associated neuropathogenesis.

Funding The authors received financial support from the Department of Biotechnology (DBT), India (Award numbers: BT/PR20922/ MED/122/37/2016,BT/PR17241/MED/30/1709/2016,BT/PR4530/ MED/30/715/2012,BT/PR14260/MED/30/437/2010); Council for Scientific and Industrial Research (CSIR), India; National Multiple Sclerosis Society, USA; M. E. Groff Surgical Medical Research and Education Charitable Trust; and Lindback Foundation Career Enhancement Award, USA, for $\mathrm{m}-\mathrm{CoV}$ research. The joint endeavor has been supported and nurtured by the Indo-U.S. Science and Technology Forum (IUSSTF) on several occasions.

\section{Compliance with ethical standards}

Competing interests The authors declare that they have no competing interests.

\section{References}

Al-Sarraj S, Troakes C, Hanley B, Osborn M, Richardson MP, Hotopf M, Bullmore E, Everall IP et al (2020)Invited review: The spectrum of neuropathology in COVID-19. Neuropathol Appl Neurobiol 1- 14

Andries K, Pensaert MB (1980) Immunofluorescence studies on the pathogenesis of hemagglutinating encephalomyelitis virus infection in pigs after oronasal inoculation. Am J Vet Res 41:1372-1378

Anghelina D, Zhao J, Trandem K, Perlman S (2009) Role of regulatory T cells in coronavirus-induced acute encephalitis. Virol 385:358-367

Arbour N, Côté G, Lachance C, Tardieu M, Cashman NR, Talbot PJ et al (1999a) Acute and persistent infection of human neural cell lines by human coronavirus OC43. J Virol 73:3338-3350

Arbour N, Day R, Newcombe J, Talbot PJ (2000) Neuroinvasion by human respiratory coronaviruses. J Virol 74:8913-8921

Arbour N, Ekandé S, Côté G, Lachance C, Chagnon F, Tardieu M, Cashman NR, Talbot PJ et al (1999b) Persistent infection of human oligodendrocytic and neuroglial cell lines by human coronavirus 229E. J Virol 73:3326-3337

Athmer J, Fehr AR, Grunewald ME, Qu W, Wheeler DL, Graepel KW, Channappanavar R, Sekine A, Aldabeeb DS, Gale M, Denison MR, Perlman S et al (2018) Selective packaging in murine coronavirus promotes virulence by limiting type i interferon responses. mBio 9:e00272-18

Bastard P, Rosen LB, Zhang Q, Michailidis E, Hoffmann H-H, Zhang Y, Dorgham K, Philippot Q, Rosain J, Béziat V, Manry J, Shaw E, Haljasmägi L, Peterson P, Lorenzo L, Bizien L, Trouillet-Assant S, Dobbs K, de Jesus AA, Belot A, Kallaste A, Catherinot E, Tandjaoui-Lambiotte Y, Le Pen J, Kerner G, Bigio B, Seeleuthner Y, Yang R, Bolze A, Spaan AN, Delmonte OM, Abers MS, Aiuti A, Casari G, Lampasona V, Piemonti L, Ciceri F, Bilguvar K, Lifton RP, Vasse M, Smadja DM, Migaud M, Hadjadj J, Terrier B, Duffy D, Quintana-Murci L, van de Beek D, Roussel L, Vinh DC, Tangye SG, Haerynck F, Dalmau D, Martinez-Picado J, Brodin P, Nussenzweig MC, Boisson-Dupuis S, Rodríguez-Gallego C, Vogt G, Mogensen TH, Oler AJ, Gu J, Burbelo PD, Cohen J, Biondi A, Bettini LR, D’Angio M, Bonfanti P, Rossignol P, Mayaux J, Rieux-Laucat F, Husebye ES, Fusco F, Ursini MV, Imberti L, Sottini A, Paghera S, Quiros-Roldan E, Rossi C, Castagnoli R, Montagna D, Licari A, Marseglia GL, Duval X, Ghosn J, Tsang JS, Goldbach-Mansky R, Kisand K, Lionakis MS, Puel A, Zhang S-Y, Holland SM, Gorochov G, Jouanguy E, Rice CM, Cobat A, Notarangelo LD, Abel L, Su HC, Casanova J-L et al (2020) Autoantibodies against type I IFNs in patients with life-threatening COVID-19. Sci 370

Bender SJ, Weiss SR (2010) Pathogenesis of murine coronavirus in the central nervous system. J Neuroimmune Pharmacol 5:336-354

Bergmann CC, Lane TE, Stohlman SA (2006) Coronavirus infection of the central nervous system: host-virus stand-off. Nat Rev Microbiol 4:121-132

Bernstein HG, Dobrowolny H, Keilhoff G, Steiner J (2018) Dipeptidyl peptidase IV, which probably plays important roles in Alzheimer disease $(\mathrm{AD})$ pathology, is upregulated in $\mathrm{AD}$ brain neurons and associates with amyloid plaques. Neurochem Int 114:55-57

Biswas K, Chatterjee D, Addya S, Khan RS, Kenyon LC, Choe A, Cohrs RJ, Shindler KS, Das Sarma J et al (2016) Demyelinating strain of mouse hepatitis virus infection bridging innate and adaptive immune response in the induction of demyelination. Clin Immunol 170:9-19

Blanco-Melo D, Nilsson-Payant BE, Liu WC, Uhl S, Hoagland D, Møller R, Jordan TX, Oishi K, Panis M, Sachs D, Wang TT, Schwartz RE, Lim JK, Albrecht RA, tenOever BR et al (2020) Imbalanced Host Response to SARS-CoV-2 Drives Development of COVID-19. Cell 181:1036-1045.e9 
Brun G, Hak J-F, Coze S, Kaphan E, Carvelli J, Girard N, Stellmann JP et al (2020) COVID-19-White matter and globus pallidum lesions. Neurol Neuroimmunol Neuroinflammation 7:e777

Butchi NB, Hinton DR, Stohlman SA, Kapil P, Fensterl V, Sen GC, Bergmann CC et al (2014) Ifit 2 deficiency results in uncontrolled neurotropic coronavirus replication and enhanced encephalitis via impaired alpha/beta interferon induction in macrophages. J Virol 88:1051-1064

Cervantes-Barragan L, Züst R, Weber F, Spiegel M, Lang KS, Akira S, Thiel V, Ludewig B et al (2007) Control of coronavirus infection through plasmacytoid dendritic-cell-derived type I interferon. Blood 109:1131-1137

Chakravarty D, Saadi F, Kundu S, Bose A, Khan R, Dine K, Kenyon LC, Shindler KS, Das Sarma J et al (2020) CD4 deficiency causes poliomyelitis and axonal blebbing in murine coronavirus induced neuroinflammation. J Virol JVI:00548-20.

Channappanavar R, Fehr AR, Vijay R, Mack M, Zhao J, Meyerholz DK, Perlman S et al (2016) Dysregulated type I interferon and inflammatory monocyte-macrophage responses cause lethal pneumonia in SARS-CoV-infected mice. Cell Host Microbe 19:181-193

Chatterjee D, Addya S, Khan RS, Kenyon LC, Choe A, Cohrs RJ, Shindler KS, Sarma JD et al (2014) Mouse hepatitis virus infection upregulates genes involved in innate immune responses. PLoS ONE 9:e111351-e111351

Chen J, Subbarao K (2007) The Immunobiology of SARS*. Annu Rev Immunol 25:443-472

Choi JY, Lee HK, Park JH, Cho SJ, Kwon M, Jo C, Koh YH et al (2020) Altered COVID-19 receptor ACE2 expression in a higher risk group for cerebrovascular disease and ischemic stroke. Biochem Biophys Res Commun 528:413-419

Chu H, Chan JFW, Yuen TTT, Shuai H, Yuan S, Wang Y, Hu B, Yip CCY, Tsang JOL, Huang X, Chai Y, Yang D, Hou Y, Chik KKH, Zhang X, Fung AYF, Tsoi HW, Cai JP, Chan WM, Ip JD, Chu AWH, Zhou J, Lung DC, Kok KH, To KKW, Tsang OTY, Chan KH, Yuen KY et al (2020) Comparative tropism, replication kinetics, and cell damage profiling of SARS-CoV-2 and SARS-CoV with implications for clinical manifestations, transmissibility, and laboratory studies of COVID-19: an observational study. The Lancet Microbe 1:e14-e23

Coperchini F, Chiovato L, Croce L, Magri F, Rotondi M (2020) The cytokine storm in COVID-19: an overview of the involvement of the chemokine/chemokine-receptor system. Cytokine Growth Factor Rev 53:25-32

Corman VM, Muth D, Niemeyer D, Drosten C (2018) Chapter Eight - Hosts and Sources of Endemic Human Coronaviruses. In: Advances in Virus Research. Kielian M, Mettenleiter TC, Roossinck MJ, (eds). Academic Press, pp 163-188

Dandekar AA, Wu GF, Pewe L, Perlman S (2001) Axonal damage is $\mathrm{T}$ cell mediated and occurs concomitantly with demyelination in mice infected with a neurotropic coronavirus. J Virol 75:6115-6120

Das Sarma J (2010) A mechanism of virus-induced demyelination. Interdiscip Perspect Infect Dis 2010:109239

Das Sarma J (2014) Microglia-mediated neuroinflammation is an amplifier of virus-induced neuropathology. Journal of NeuroVirology 20:122-136

Das Sarma J, Fu L, Hingley ST, Lavi E (2001) Mouse hepatitis virus type-2 infection in mice: an experimental model system of acute meningitis and hepatitis. Exp Mol Pathol 71:1-12

Das Sarma J, Fu L, Tsai JC, Weiss SR, Lavi E (2000) Demyelination determinants map to the spike glycoprotein gene of coronavirus mouse hepatitis virus. J Virol 74:9206

Das Sarma J, Iacono K, Gard L, Marek R, Kenyon LC, Koval M, Weiss SR et al (2008) Demyelinating and nondemyelinating strains of mouse hepatitis virus differ in their neural cell tropism. J Virol 82:5519
Das Sarma J, Kenyon LC, Hingley ST, Shindler KS (2009) Mechanisms of primary axonal damage in a viral model of multiple sclerosis. J Neurosci 29:10272

Das Sarma J, Scheen E, Seo SH, Koval M, Weiss SR (2002) Enhanced green fluorescent protein expression may be used to monitor murine coronavirus spread in vitro and in the mouse central nervous system. Journal of NeuroVirology 8:381-391

Das Sarma J, Burrows A, Rayman P, Hwang MH, Kundu S et al (2020) Ifit 2 deficiency restricts microglial activation and leukocyte migration following murine coronavirus (m-CoV) CNS infection. PLOS Pathogens 16(11):e1009034. https://doi. org/10.1371/journal.ppat.1009034

De Albuquerque N, Baig E, Ma X, Zhang J, He W, Rowe A, Habal M, Liu M, Shalev I, Downey GP, Gorczynski R, Butany J, Leibowitz J, Weiss SR, McGilvray ID, Phillips MJ, Fish EN, Levy GA et al (2006) Murine hepatitis virus strain 1 produces a clinically relevant model of severe acute respiratory syndrome in $\mathrm{A} / \mathrm{J}$ mice. $\mathrm{J}$ Virol 80:10382

de Wilde AH, Snijder EJ, Kikkert M, van Hemert MJ (2018) Host factors in coronavirus replication. Curr Top Microbiol Immunol 419:1-42

de Wit E, van Doremalen N, Falzarano D, Munster VJ (2016) SARS and MERS: recent insights into emerging coronaviruses. Nat Rev Microbiol 14:523-534

Ding Z, Fang L, Yuan S, Zhao L, Wang X, Long S, Wang M, Wang D, Foda MF, Xiao $S$ et al (2017) The nucleocapsid proteins of mouse hepatitis virus and severe acute respiratory syndrome coronavirus share the same IFN- $\beta$ antagonizing mechanism: attenuation of PACT-mediated RIG-I/ MDA5 activation. Oncotarget 8:49655-49670

Du L, He Y, Zhou Y, Liu S, Zheng BJ, Jiang S (2009) The spike protein of SARS-CoV-a target for vaccine and therapeutic development. Nat Rev Microbiol 7:226-236

Dubé M, Le Coupanec A, Wong AHM, Rini JM, Desforges M, Talbot $\mathrm{PJ}$ et al (2018) Axonal transport enables neuron-to-neuron propagation of human coronavirus OC43. J Virol 92:e00404-e418

Esper F, Weibel C, Ferguson D, Landry ML, Kahn JS (2005) Evidence of a novel human coronavirus that is associated with respiratory tract disease in infants and young children. J Infect Dis 191:492-498

Fehr AR, Perlman S (2015) Coronaviruses: an overview of their replication and pathogenesis. Methods Mol Biol (Clifton, NJ) 1282:1-23

Fleming JO, Trousdale MD, el-Zaatari FA, Stohlman SA, Weiner LP (1986) Pathogenicity of antigenic variants of murine coronavirus JHM selected with monoclonal antibodies. J Virol 58:869-875

Forni D, Cagliani R, Clerici M, Sironi M (2017) Molecular evolution of human coronavirus genomes. Trends Microbiol 25:35-48

Frontera JA (2012) Metabolic encephalopathies in the critical care unit. Continuum (Minneap Minn) 18:611-639

García LF (2020) Immune response, inflammation, and the clinical spectrum of COVID-19. Front Immunol 11:1441

Gautier JF, Ravussin Y (2020) A new symptom of COVID-19: loss of taste and smell. Obesity 28:848-848

Glass WG, Subbarao K, Murphy B, Murphy PM (2004) Mechanisms of host defense following severe acute respiratory syndromecoronavirus (SARS-CoV) pulmonary infection of mice. J Immunol 173:4030-4039

González-Pinto T, Luna-Rodríguez A, Moreno-Estébanez A, AgirreBeitia G, Rodríguez-Antigüedad A, Ruiz-Lopez M et al (2020) Emergency room neurology in times of COVID-19: malignant ischaemic stroke and SARS-CoV-2 infection. Eur J Neurol 27:e35-e36

González JM, Bergmann CC, Ramakrishna C, Hinton DR, Atkinson R, Hoskin J, Macklin WB, Stohlman SA et al (2006) Inhibition of interferon-gamma signaling in oligodendroglia delays 
coronavirus clearance without altering demyelination. Am J Pathol 168:796-804

Gu J, Gong E, Zhang B, Zheng J, Gao Z, Zhong Y, Zou W, Zhan J, Wang S, Xie Z, Zhuang H, Wu B, Zhong H, Shao H, Fang W, Gao D, Pei F, Li X, He Z, Xu D, Shi X, Anderson VM, Leong AS et al (2005) Multiple organ infection and the pathogenesis of SARS. J Exp Med 202:415-424

Gu J, Korteweg C (2007) Pathology and pathogenesis of severe acute respiratory syndrome. Am J Pathol 170:1136-1147

Guan WJ, Ni ZY, Hu Y, Liang WH, Ou CQ, He JX, Liu L, Shan H, Lei CL, Hui DSC, Du B, Li LJ, Zeng G, Yuen KY, Chen RC, Tang CL, Wang T, Chen PY, Xiang J, Li SY, Wang JL, Liang ZJ, Peng YX, Wei L, Liu Y, Hu YH, Peng P, Wang JM, Liu JY, Chen Z, Li G, Zheng ZJ, Qiu SQ, Luo J, Ye CJ, Zhu SY, Zhong NS et al (2020) Clinical characteristics of coronavirus disease 2019 in China. N Engl J Med 382:1708-1720

Gutiérrez-Ortiz C, Méndez A, Rodrigo-Rey S, San Pedro-Murillo E, Bermejo-Guerrero L, Gordo-Mañas R, de Aragón-Gómez F, Benito-León J et al (2020) Miller Fisher Syndrome and polyneuritis cranialis in COVID-19. Neurol

Hadziefendic S, Haxhiu MA (1999) CNS innervation of vagal preganglionic neurons controlling peripheral airways: a transneuronal labeling study using pseudorabies virus. J Auton Nerv Syst 76:135-145

Hanley B, Naresh KN, Roufosse C, Nicholson AG, Weir J, Cooke GS, Thursz M, Manousou P, Corbett R, Goldin R, Al-Sarraj S, Abdolrasouli A, Swann OC, Baillon L, Penn R, Barclay WS, Viola P, Osborn M et al (2020) Histopathological findings and viral tropism in UK patients with severe fatal COVID-19: a postmortem study. Lancet Microbe 1:e245-e253

Helms J, Kremer S, Merdji H, Clere-Jehl R, Schenck M, Kummerlen C, Collange O, Boulay C, Fafi-Kremer S, Ohana M, Anheim M, Meziani F (2020) Neurologic features in severe SARS-CoV-2 infection. N Engl J Med 382:2268-2270

Henderson LA, Canna SW, Schulert GS, Volpi S, Lee PY, Kernan KF, Caricchio R, Mahmud S, Hazen MM, Halyabar O, Hoyt KJ, Han J, Grom AA, Gattorno M, Ravelli A, De Benedetti F, Behrens EM, Cron RQ, Nigrovic PA (2020) On the alert for cytokine storm: immunopathology in COVID-19. Arthritis \& Rheumatology 72:1059-1063

Hoffmann M, Kleine-Weber H, Schroeder S, Krüger N, Herrler T, Erichsen S, Schiergens TS, Herrler G, Wu N-H, Nitsche A, Müller MA, Drosten C, Pöhlmann S (2020) SARS-CoV-2 cell entry depends on ACE2 and TMPRSS2 and is blocked by a clinically proven protease inhibitor. Cell 181:271-280.e8

Hosking MP, Lane TE (2010) The role of chemokines during viral infection of the CNS. PLoS Pathog 6:e1000937-e1000937

Houtman JJ, Fleming JO (1996) Pathogenesis of mouse hepatitis virusinduced demyelination. J Neurovirol 2:361-376

Huang C, Wang Y, Li X, Ren L, Zhao J, Hu Y, Zhang L, Fan G, Xu J, Gu X, Cheng Z, Yu T, Xia J, Wei Y, Wu W, Xie X, Yin W, Li H, Liu M, Xiao Y, Gao H, Guo L, Xie J, Wang G, Jiang R, Gao Z, Jin Q, Wang J, Cao B et al (2020) Clinical features of patients infected with 2019 novel coronavirus in Wuhan, China. The Lancet 395:497-506

Hung ECW, Chim SSC, Chan PKS, Tong YK, Ng EKO, Chiu RWK, Leung CB, Sung JJY, Tam JS, Lo YMD (2003) Detection of SARS Coronavirus RNA in the cerebrospinal fluid of a patient with severe acute respiratory syndrome. Clin Chem 49:2108-2109

Hwang M, Bergmann CC (2018) Alpha/Beta Interferon (IFN- $\alpha / \beta$ ) Signaling in Astrocytes Mediates Protection against Viral Encephalomyelitis and Regulates IFN- $\boldsymbol{\gamma}$-Dependent Responses. J Virol 92

Hwang M, Bergmann CC (2019) Intercellular communication is key for protective IFN $\alpha / \beta$ signaling during viral central nervous system infection. Viral Immunol 32:1-6
Ivashkiv LB, Donlin LT (2014) Regulation of type I interferon responses. Nat Rev Immunol 14:36-49

Jacomy H, Fragoso G, Almazan G, Mushynski WE, Talbot PJ (2006) Human coronavirus OC43 infection induces chronic encephalitis leading to disabilities in BALB/C mice. Virology 349:335-346

Jacomy H, Talbot PJ (2003) Vacuolating encephalitis in mice infected by human coronavirus OC43. Virology 315:20-33

Kalia M, Mesulam MM (1980) Brain stem projections of sensory and motor components of the vagus complex in the cat: II. Laryngeal, tracheobronchial, pulmonary, cardiac, and gastrointestinal branches. J Comp Neurol 193:467-508

Kanberg N, Ashton NJ, Andersson L-M, Yilmaz A, Lindh M, Nilsson S, Price RW, Blennow K, Zetterberg H, Gisslén M et al (2020) Neurochemical evidence of astrocytic and neuronal injury commonly found in COVID-19. Neurol Neuroimmunol Neuroinflammation 95(12):e1754-e1759

Kenyon LC, Biswas K, Shindler KS, Nabar M, Stout M, Hingley ST, Grinspan JB, Das Sarma J et al (2015) Gliopathy of demyelinating and non-demyelinating strains of mouse hepatitis virus. Front Cell Neurosci 9

Kim JE, Heo JH, Kim HO, Song SH, Park SS, Park TH, Ahn JY, Kim MK, Choi JP (2017) Neurological Complications during treatment of Middle East respiratory syndrome. J Clin Neurol 13:227-233

Koralnik IJ, Tyler KL (2020) COVID-19: a global threat to the nervous system. Ann Neurol 88:1-11

Lane TE, Buchmeier MJ (1997) Murine coronavirus infection: a paradigm for virus-induced demyelinating disease. Trends Microbiol 5:9-14

Lane TE, Hosking MP (2010) The pathogenesis of murine coronavirus infection of the central nervous system. Crit Rev Immunol 30:119-130

Lane TE, Liu MT, Chen BP, Asensio VC, Samawi RM, Paoletti AD, Campbell IL, Kunkel SL, Fox HS, Buchmeier MJ et al (2000) A central role for CD4(+) T cells and RANTES in virus-induced central nervous system inflammation and demyelination. J Virol 74:1415-1424

Lau KK, Yu WC, Chu CM, Lau ST, Sheng B, Yuen KY (2004) Possible central nervous system infection by SARS coronavirus. Emerg Infect Dis 10:342-344

Lavi E, Cong L (2020) Type I astrocytes and microglia induce a cytokine response in an encephalitic murine coronavirus infection. Exp Mol Pathol 115:104474-104474

Lavi E, Gilden DH, Highkin MK, Weiss SR (1984a) Persistence of mouse hepatitis virus A59 RNA in a slow virus demyelinating infection in mice as detected by in situ hybridization. J Virol 51:563-566

Lavi E, Gilden DH, Wroblewska Z, Rorke LB, Weiss SR (1984b) Experimental demyelination produced by the A59 strain of mouse hepatitis virus. Neurology 34:597-603

Lei L, Ying S, Baojun L, Yi Y, Xiang H, Wenli S, Zounan S, Deyin G, Qingyu Z, Jingmei L, Guohui C et al (2013) Attenuation of mouse hepatitis virus by deletion of the LLRKxGxKG region of Nsp1. PLoS ONE 8:e61166

Letko M, Marzi A, Munster V (2020) Functional assessment of cell entry and receptor usage for SARS-CoV-2 and other lineage B betacoronaviruses. Nat Microbiol 5:562-569

Li F (2015) Receptor recognition mechanisms of coronaviruses: a decade of structural studies. J Virol 89:1954

Li W, Moore MJ, Vasilieva N, Sui J, Wong SK, Berne MA, Somasundaran M, Sullivan JL, Luzuriaga K, Greenough TC, Choe H, Farzan M et al (2003) Angiotensin-converting enzyme 2 is a functional receptor for the SARS coronavirus. Nat 426:450-454 
Li YC, Bai WZ, Hashikawa T (2020) The neuroinvasive potential of SARS-CoV2 may play a role in the respiratory failure of COVID-19 patients. J Med Virol 92:552-555

Li YC, Bai WZ, Hirano N, Hayashida T, Hashikawa T (2012) Coronavirus infection of rat dorsal root ganglia: ultrastructural characterization of viral replication, transfer, and the early response of satellite cells. Virus Res 163:628-635

Liao M, Liu Y, Yuan J, Wen Y, Xu G, Zhao J, Cheng L, Li J, Wang X, Wang F, Liu L, Amit I, Zhang S, Zhang Z et al (2020) Single-cell landscape of bronchoalveolar immune cells in patients with COVID-19. Nat Med 26:842-844

Lin MT, Stohlman SA, Hinton DR (1997) Mouse hepatitis virus is cleared from the central nervous systems of mice lacking perforin-mediated cytolysis. J Virol 71:383-391

Liu MT, Lane TE (2001) Chemokine expression and viral infection of the central nervous system: regulation of host defense and neuropathology. Immunol Res 24:111-119

Lu L, Xiong W, Liu D, Liu J, Yang D, Li N, Mu J, Guo J, Li W, Wang G, Gao H, Zhang Y, Lin M, Chen L, Shen S, Zhang H, Sander JW, Luo J, Chen S, Zhou D et al (2020) New onset acute symptomatic seizure and risk factors in coronavirus disease 2019: a retrospective multicenter study. Epilepsia 61:e49-e53

Manganelli F, Vargas M, Iovino A, Iacovazzo C, Santoro L, Servillo G (2020) Brainstem involvement and respiratory failure in COVID-19. Neurological sciences : official journal of the Italian Neurological Society and of the Italian Society of Clinical Neurophysiology 41:1663-1665

Mao L, Wang M, Chen S, He Q, Chang J, Hong C, Zhou Y, Wang D, Li Y, Jin H, Hu B et al (2020) Neurological manifestations of hospitalized patients with COVID-19 in Wuhan, China: a retrospective case series study. medRxiv:2020.02.22.20026500.

Marten NW, Stohlman SA, Zhou J, Bergmann CC (2003) Kinetics of virus-specific $\mathrm{CD} 8+-\mathrm{T}$-cell expansion and trafficking following central nervous system infection. J Virol 77:2775-2778

Matschke J, Lütgehetmann M, Hagel C, Sperhake JP, Schröder AS, Edler C, Mushumba H, Fitzek A, Allweiss L, Dandri M, Dottermusch M, Heinemann A, Pfefferle S, Schwabenland M, Sumner Magruder D, Bonn S, Prinz M, Gerloff C, Püschel K, Krasemann S, Aepfelbacher M, Glatzel M et al (2020) Neuropathology of patients with COVID19 in Germany: a post-mortem case series. Lancet Neurol

Menter T, Haslbauer JD, Nienhold R, Savic S, Deigendesch H, Frank S, Turek D, Willi N, Pargger H, Bassetti S, Leuppi JD, Cathomas G, Tolnay M, Mertz KD, Tzankov A et al (2020 Postmortem examination of COVID-19 patients reveals diffuse alveolar damage with severe capillary congestion and variegated findings in lungs and other organs suggesting vascular dysfunction. Histopathology n/a

Merad M, Martin JC (2020) Pathological inflammation in patients with COVID-19: a key role for monocytes and macrophages. Nat Rev Immunol

Miura TA, Travanty EA, Oko L, Bielefeldt-Ohmann H, Weiss SR, Beauchemin N, Holmes KV et al (2008) The spike glycoprotein of murine coronavirus MHV-JHM mediates receptor-independent infection and spread in the central nervous systems of Ceacam1a-/Mice. J Virol 82:755-763

Mordstein M, Neugebauer E, Ditt V, Jessen B, Rieger T, Falcone V, Sorgeloos F, Ehl S, Mayer D, Kochs G, Schwemmle M, Günther S, Drosten C, Michiels T, Staeheli P et al (2010) Lambda interferon renders epithelial cells of the respiratory and gastrointestinal tracts resistant to viral infections. J Virol 84:5670-5677

Morfopoulou S, Brown JR, Davies EG, Anderson G, Virasami A, Qasim W, Chong WK, Hubank M, Plagnol V, Desforges M, Jacques TS, Talbot PJ, Breuer J (2016) Human coronavirus OC43 associated with fatal encephalitis. N Engl J Med 375:497-498

Moriguchi T, Harii N, Goto J, Harada D, Sugawara H, Takamino J, Ueno M, Sakata H, Kondo K, Myose N, Nakao A, Takeda
M, Haro H, Inoue O, Suzuki-Inoue K, Kubokawa K, Ogihara S, Sasaki T, Kinouchi H, Kojin H, Ito M, Onishi H, Shimizu T, Sasaki Y, Enomoto N, Ishihara H, Furuya S, Yamamoto T, Shimada S et al (2020) A first case of meningitis/encephalitis associated with SARS-Coronavirus-2. Int J Infect Dis 94:55-58

Muñoz-Fontela C, Dowling WE, Funnell SGP, Gsell PS, RiverosBalta AX, Albrecht RA, Andersen H, Baric RS, Carroll MW, Cavaleri M, Qin C, Crozier I, Dallmeier K, de Waal L, de Wit E, Delang L, Dohm E, Duprex WP, Falzarano D, Finch CL, Frieman MB, Graham BS, Gralinski LE, Guilfoyle K, Haagmans BL, Hamilton GA, Hartman AL, Herfst S, Kaptein SJF, Klimstra WB, Knezevic I, Krause PR, Kuhn JH, Le Grand R, Lewis MG, Liu WC, Maisonnasse P, McElroy AK, Munster V, Oreshkova N, Rasmussen AL, Rocha-Pereira J, Rockx B, Rodríguez E, Rogers TF, Salguero FJ, Schotsaert M, Stittelaar KJ, Thibaut HJ, Tseng CT, Vergara-Alert J, Beer M, Brasel T, Chan JFW, García-Sastre A, Neyts J, Perlman S, Reed DS, Richt JA, Roy CJ, Segalés J, Vasan SS, Henao-Restrepo AM, Barouch DH et al (2020) Animal models for COVID-19. Nat 586:509-515

Navas S, Weiss SR (2003) Murine coronavirus-induced hepatitis: JHM genetic background eliminates A59 spike-determined hepatotropism. J Virol 77:4972-4978

Netland J, Meyerholz DK, Moore S, Cassell M, Perlman S (2008) Severe acute respiratory syndrome coronavirus infection causes neuronal death in the absence of encephalitis in mice transgenic for human ACE2. J Virol 82:7264

Oxley TJ, Mocco J, Majidi S, Kellner CP, Shoirah H, Singh IP, De Leacy RA, Shigematsu T, Ladner TR, Yaeger KA, Skliut M, Weinberger J, Dangayach NS, Bederson JB, Tuhrim S, Fifi JT et al (2020) Large-vessel stroke as a presenting feature of Covid-19 in the young. N Engl J Med 382:e60

Perlman S, Jacobsen G, Afifi A (1989) Spread of a neurotropic murine coronavirus into the CNS via the trigeminal and olfactory nerves. Virology 170:556-560

Perlman S, Jacobsen G, Olson AL, Afifi A (1990) Identification of the spinal cord as a major site of persistence during chronic infection with a murine coronavirus. Virology 175:418-426

Perlman S, Netland J (2009) Coronaviruses post-SARS: update on replication and pathogenesis. Nat Rev Microbiol 7:439-450

Phares TW, Stohlman SA, Hinton DR, Bergmann CC (2013) Astrocyte-derived CXCL10 drives accumulation of antibodysecreting cells in the central nervous system during viral encephalomyelitis. J Virol 87:3382-3392

Phillips JJ, Chua MM, Lavi E, Weiss SR (1999) Pathogenesis of chimeric MHV4/MHV-A59 recombinant viruses: the murine coronavirus spike protein is a major determinant of neurovirulence. J Virol 73:7752

Phillips JJ, Chua MM, Rall GF, Weiss SR (2002) Murine coronavirus spike glycoprotein mediates degree of viral spread, inflammation, and virus-induced immunopathology in the central nervous system. Virology 301:109-120

Poyiadji N, Shahin G, Noujaim D, Stone M, Patel S, Griffith B et al (2020) COVID-19-associated acute hemorrhagic necrotizing encephalopathy: imaging features. Radiol 296:E119-E120

Raj VS, Mou H, Smits SL, Dekkers DH, Müller MA, Dijkman R, Muth D, Demmers JA, Zaki A, Fouchier RA, Thiel V, Drosten C, Rottier PJ, Osterhaus AD, Bosch BJ, Haagmans BL et al (2013) Dipeptidyl peptidase 4 is a functional receptor for the emerging human coronavirus-EMC. Nat 495:251-254

Reichard RR, Kashani KB, Boire NA, Constantopoulos E, Guo Y, Lucchinetti CF et al (2020) Neuropathology of COVID-19: a spectrum of vascular and acute disseminated encephalomyelitis (ADEM)-like pathology. Acta Neuropathol 140:1-6

Rempel JD, Murray SJ, Meisner J, Buchmeier MJ (2004) Differential regulation of innate and adaptive immune responses in viral encephalitis. Virology 318:381-392 
Roth-Cross JK, Martínez-Sobrido L, Scott EP, García-Sastre A, Weiss SR (2007) Inhibition of the alpha/beta interferon response by mouse hepatitis virus at multiple levels. J Virol 81:7189

Rout SS, Singh M, Shindler KS, Das Sarma J (2020) One proline deletion in the fusion peptide of neurotropic mouse hepatitis virus (MHV) restricts retrograde axonal transport and neurodegeneration. J Biol Chem

Sarma JD, Fu L, Hingley ST, Lavi E (2001) Mouse hepatitis virus type-2 infection in mice: an experimental model system of acute meningitis and hepatitis. Exp Mol Pathol 71:1-12

Savarin C, Bergmann CC (2018) Fine tuning the cytokine storm by IFN and IL-10 following neurotropic coronavirus encephalomyelitis. Front Immunol 9:3022-3022

Schaefer IM, Padera RF, Solomon IH, Kanjilal S, Hammer MM, Hornick JL, Sholl LM et al (2020) In situ detection of SARS-CoV-2 in lungs and airways of patients with COVID-19. Mod Pathol

Shang J, Wan Y, Luo C, Ye G, Geng Q, Auerbach A, Li F (2020) Cell entry mechanisms of SARS-CoV-2. Proc Natl Acad Sci 117:11727

Shang J, Ye G, Shi K, Wan Y, Luo C, Aihara H, Geng Q, Auerbach A, Li F et al (2020) Structural basis of receptor recognition by SARS-CoV-2. Nat 581:221-224

Shindler KS, Chatterjee D, Biswas K, Goyal A, Dutt M, Nassrallah M, Khan RS, Das Sarma J (2011) Macrophage-mediated optic neuritis induced by retrograde axonal transport of spike gene recombinant mouse hepatitis virus. J Neuropathol Exp Neurol 70:470-480

Shindler KS, Kenyon LC, Dutt M, Hingley ST, Sarma JD (2008) Experimental optic neuritis induced by a demyelinating strain of mouse hepatitis virus. J Virol 82:8882

Shirato K, Kawase M, Matsuyama S (2013) Middle East respiratory syndrome coronavirus infection mediated by the transmembrane serine protease TMPRSS2. J Virol 87:12552-12561

Singh M, Kishore A, Maity D, Sunanda P, Krishnarjuna B, Vappala S, Raghothama S, Kenyon LC, Pal D, Das Sarma J et al (2019) A proline insertion-deletion in the spike glycoprotein fusion peptide of mouse hepatitis virus strongly alters neuropathology. J Biol Chem 294:8064-8087

Stohlman SA, Weiner LP (1981) Chronic central nervous system demyelination in mice after JHM virus infection. Neurology 31:38-44

Su S, Wong G, Shi W, Liu J, Lai ACK, Zhou J, Liu W, Bi Y, Gao GF et al (2016) Epidemiology, genetic recombination, and pathogenesis of coronaviruses. Trends Microbiol 24:490-502

Talbot PJ, Ékandé S, Cashman NR, Mounir S, Stewart JN (1993) Neurotropism of human coronavirus 229E. In: Coronaviruses: molecular biology and virus-host interactions. Laude $\mathrm{H}$, Vautherot J-F, (eds). Springer US: Boston, MA, pp 339-346

Tardieu M, Boespflug O, Barbé T (1986) Selective tropism of a neurotropic coronavirus for ependymal cells, neurons, and meningeal cells. J Virol 60:574-582

Tardieu M, Goffinet A, Harmant-van Rijckevorsel G, Lyon G (1982) Ependymitis, leukoencephalitis, hydrocephalus, and thrombotic vasculitis following chronic infection by mouse hepatitis virus 3 (MHV 3). Acta Neuropathol 58:168-176

Tay MZ, Poh CM, Rénia L, MacAry PA, Ng LFP (2020) The trinity of COVID-19: immunity, inflammation and intervention. Nat Rev Immunol

Toscano G, Palmerini F, Ravaglia S, Ruiz L, Invernizzi P, Cuzzoni MG, Franciotta D, Baldanti F, Daturi R, Postorino P, Cavallini A, Micieli G et al (2020) Guillain-Barré syndrome associated with SARS-CoV-2. N Engl J Med 382:2574-2576

Tseng CTK, Huang C, Newman P, Wang N, Narayanan K, Watts DM, Makino S, Packard MM, Zaki SR, Chan TS, Peters CJ et al (2007) Severe acute respiratory syndrome coronavirus infection of mice transgenic for the human angiotensin-converting enzyme 2 virus receptor. J Virol 81:1162
Turgay C, Emine T, Ozlem K, Muhammet S, Haydar A (2015) A rare cause of acute flaccid paralysis: Human coronaviruses $10: 280-281$

van der Hoek L (2007) Human coronaviruses: what do they cause? Antivir Ther 12:651-658

van der Hoek L, Pyrc K, Berkhout B (2006) Human coronavirus NL63, a new respiratory virus. FEMS Microbiol Rev 30:760-773

Varga Z, Flammer AJ, Steiger P, Haberecker M, Andermatt R, Zinkernagel AS, Mehra MR, Schuepbach RA, Ruschitzka F, Moch $\mathrm{H}$ et al (2020) Endothelial cell infection and endotheliitis in COVID-19. Lancet (London, England) 395:1417-1418

Walls AC, Park YJ, Tortorici MA, Wall A, McGuire AT, Veesler D et al (2020) Structure, function, and antigenicity of the SARS-CoV-2 spike glycoprotein. Cell 181:281-292.e6

Walls AC, Tortorici MA, Bosch BJ, Frenz B, Rottier PJM, DiMaio F, Rey FA, Veesler D et al (2016) Cryo-electron microscopy structure of a coronavirus spike glycoprotein trimer. Nat 531:114-117

Wang G, Chen G, Zheng D, Cheng G, Tang H (2011) PLP2 of mouse hepatitis virus A59 (MHV-A59) targets TBK1 to negatively regulate cellular type I interferon signaling pathway. PLoS ONE 6:e17192-e17192

Wang K, Gheblawi M, Oudit Gavin Y (2020) Angiotensin converting enzyme 2: a double-edged sword. Circ 0

Weiss SR, Leibowitz JL (2011) Coronavirus pathogenesis. Adv Virus Res 81:85-164

Weiss SR, Navas-Martin S (2005) Coronavirus pathogenesis and the emerging pathogen severe acute respiratory syndrome coronavirus. Microbiol Mol Biol Rev 69:635

Woo PC, Lau SK, Tsoi HW, Huang Y, Poon RW, Chu CM, Lee RA, Luk WK, Wong GK, Wong BH, Cheng VC, Tang BS, Wu AK, Yung RW, Chen H, Guan Y, Chan KH, Yuen KY et al (2005) Clinical and molecular epidemiological features of coronavirus HKU1-associated community-acquired pneumonia. J Infect Dis 192:1898-1907

Wrapp D, Wang N, Corbett KS, Goldsmith JA, Hsieh CL, Abiona O, Graham BS, McLellan JS et al (2020) Cryo-EM structure of the 2019-nCoV spike in the prefusion conformation. Sci 367:1260-1263

Wu D, Wu T, Liu Q, Yang Z (2020) The SARS-CoV-2 outbreak: what we know. International journal of infectious diseases : IJID : official publication of the International Society for Infectious Diseases 94:44-48

Wu GF, Dandekar AA, Pewe L, Perlman S (2000) CD4 and CD8 T cells have redundant but not identical roles in virus-induced demyelination. J Immunol (Baltimore, Md : 1950) 165:2278-2286

Wu Y, Xu X, Chen Z, Duan J, Hashimoto K, Yang L, Liu C, Yang $C$ et al (2020) Nervous system involvement after infection with COVID-19 and other coronaviruses. Brain Behav Immun 87:18-22

Xu H, Zhong L, Deng J, Peng J, Dan H, Zeng X, Li T, Chen Q (2020a) High expression of ACE2 receptor of $2019-\mathrm{nCoV}$ on the epithelial cells of oral mucosa. Int J Oral Sci 12:8

Xu Z, Shi L, Wang Y, Zhang J, Huang L, Zhang C, Liu S, Zhao P, Liu H, Zhu L, Tai Y, Bai C, Gao T, Song J, Xia P, Dong J, Zhao J, Wang FS et al (2020b) Pathological findings of COVID19 associated with acute respiratory distress syndrome. Lancet Respir Med 8:420-422

Ye Y, Hauns K, Langland JO, Jacobs BL, Hogue BG (2007) Mouse hepatitis coronavirus A59 nucleocapsid protein is a type I interferon antagonist. J Virol 81:2554-2563

Zanin L, Saraceno G, Panciani PP, Renisi G, Signorini L, Migliorati K, Fontanella MM et al (2020) SARS-CoV-2 can induce brain and spine demyelinating lesions. Acta Neurochir 162:1491-1494

Zhang Q, Bastard P, Liu Z, Le Pen J, Moncada-Velez M, Chen J, Ogishi M, Sabli IKD, Hodeib S, Korol C, Rosain J, Bilguvar K, Ye J, 
Bolze A, Bigio B, Yang R, Arias AA, Zhou Q, Zhang Y, Onodi F, Korniotis S, Karpf L, Philippot Q, Chbihi M, Bonnet-Madin L, Dorgham K, Smith N, Schneider WM, Razooky BS, Hoffmann HH, Michailidis E, Moens L, Han JE, Lorenzo L, Bizien L, Meade P, Neehus AL, Ugurbil AC, Corneau A, Kerner G, Zhang P, Rapaport F, Seeleuthner Y, Manry J, Masson C, Schmitt Y, Schlüter A, Le Voyer T, Khan T, Li J, Fellay J, Roussel L, Shahrooei M, Alosaimi MF, Mansouri D, Al-Saud H, Al-Mulla F, Almourfi F, Al-Muhsen SZ, Alsohime F, Al Turki S, Hasanato R, van de Beek D, Biondi A, Bettini LR, D'Angio M, Bonfanti P, Imberti L, Sottini A, Paghera S, Quiros-Roldan E, Rossi C, Oler AJ, Tompkins MF, Alba C, Vandernoot I, Goffard JC, Smits G, Migeotte I, Haerynck F, Soler-Palacin P, Martin-Nalda A, Colobran R, Morange P-E, Keles S, Çölkesen F, Ozcelik T, Yasar KK, Senoglu S, Karabela ŞN, Gallego CR, Novelli G, Hraiech S, Tandjaoui-Lambiotte Y, Duval X, Laouénan C, Snow AL, Dalgard CL, Milner J, Vinh DC, et al (2020) Inborn errors of type I IFN immunity in patients with life-threatening COVID19. Sci 370

Zhao L, Birdwell LD, Wu A, Elliott R, Rose KM, Phillips JM, Li Y, Grinspan J, Silverman RH, Weiss SR et al (2013) Cell-typespecific activation of the oligoadenylate synthetase-RNase L pathway by a murine coronavirus. J Virol 87:8408

Zhao L, Jha Babal K, Wu A, Elliott R, Ziebuhr J, Gorbalenya Alexander E, Silverman Robert H, Weiss Susan R et al (2012) Antagonism of the interferon-induced OAS-RNase L Pathway by murine coronavirus ns 2 protein is required for virus replication and liver pathology. Cell Host Microbe 11:607-616

Zheng HY, Zhang M, Yang CX, Zhang N, Wang XC, Yang XP, Dong XQ, Zheng YT et al (2020) Elevated exhaustion levels and reduced functional diversity of $\mathrm{T}$ cells in peripheral blood may predict severe progression in COVID-19 patients. Cell Mol Immunol 17:541-543

Zhou P, Yang XL, Wang XG, Hu B, Zhang L, Zhang W, Si HR, Zhu Y, Li B, Huang CL, Chen HD, Chen J, Luo Y, Guo H, Jiang RD, Liu MQ, Chen Y, Shen XR, Wang X, Zheng XS, Zhao K, Chen QJ, Deng F, Liu LL, Yan B, Zhan FX, Wang YY, Xiao GF, Shi ZL et al (2020a) A pneumonia outbreak associated with a new coronavirus of probable bat origin. Nat 579:270-273
Zhou Y, Fu B, Zheng X, Wang D, Zhao C, Qi Y, Sun R, Tian Z, Xu X, Wei H (2020b). Pathogenic T cells and inflammatory monocytes incite inflammatory storm in severe COVID-19 patients. Natl Scie Rev nwaa041

Zhu N, Zhang D, Wang W, Li X, Yang B, Song J, Zhao X, Huang B, Shi W, Lu R, Niu P, Zhan F, Ma X, Wang D, Xu W, Wu G, Gao GF, Tan W et al (2020) A novel coronavirus from patients with pneumonia in China, 2019. N Engl J Med 382:727-733

Ziegler CGK, Allon SJ, Nyquist SK, Mbano IM, Miao VN, Tzouanas CN, Cao Y, Yousif AS, Bals J, Hauser BM, Feldman J, Muus C, Wadsworth MH, Kazer SW, Hughes TK, Doran B, Gatter GJ, Vukovic M, Taliaferro F, Mead BE, Guo Z, Wang JP, Gras D, Plaisant M, Ansari M, Angelidis I, Adler H, Sucre JMS, Taylor CJ, Lin B, Waghray A, Mitsialis V, Dwyer DF, Buchheit KM, Boyce JA, Barrett NA, Laidlaw TM, Carroll SL, Colonna L, Tkachev V, Peterson CW, Yu A, Zheng HB, Gideon HP, Winchell CG, Lin PL, Bingle CD, Snapper SB, Kropski JA, Theis FJ, Schiller HB, Zaragosi L-E, Barbry P, Leslie A, Kiem H-P, Flynn JL, Fortune SM, Berger B, Finberg RW, Kean LS, Garber M, Schmidt AG, Lingwood D, Shalek AK, OrdovasMontanes J, Banovich N, Barbry P, Brazma A, Desai T, Duong TE, Eickelberg O, Falk C, Farzan M, Glass I, Haniffa M, Horvath P, Hung D, Kaminski N, Krasnow M, Kropski JA, Kuhnemund M, Lafyatis R, Lee H, Leroy S, Linnarson S, Lundeberg J, Meyer K, Misharin A, Nawijn M, Nikolic MZ, Ordovas-Montanes J, Pe'er D, Powell J, Quake S, Rajagopal J, Tata PR, Rawlins EL, Regev A, Reyfman PA, Rojas M, et al (2020) SARS-CoV-2 receptor ACE2 is an interferon-stimulated gene in human airway epithelial cells and is detected in specific cell subsets across tissues. Cell 181:1016-1035.e19

Zoghi A, Ramezani M, Roozbeh M, Darazam IA, Sahraian MA (2020) A case of possible atypical demyelinating event of the central nervous system following COVID-19. Mult Scler Relat Disord 44:102324

Publisher's Note Springer Nature remains neutral with regard to jurisdictional claims in published maps and institutional affiliations. 